\title{
Altruism born of suffering? The impact of an adverse health shock on pro-social behaviour
}

\author{
Nicole Black \\ Elaine De Gruyter \\ Dennis Petrie \\ Sarah Smith
}

Discussion Paper 20 / 736

10 December 2020

2. University of

School of Economics

University of Bristol

Priory Road Complex

Bristol BS8 1TU

United Kingdom 
Altruism born of suffering? The impact of an adverse health shock on pro-social behaviour

\section{Authors (listed alphabetically)}

Nicole Black

Centre for Health Economics, Monash Business School,

Monash University

900 Dandenong Road

Caulfield East, Victoria 3145

Australia

Email: nicole.black@monash.edu

Elaine De Gruyter (corresponding author)

Centre for Health Economics, Monash Business School,

Monash University

900 Dandenong Road

Caulfield East, Victoria 3145

Australia

Email: elaine.degruyter@monash.edu

Dennis Petrie

Centre for Health Economics, Monash Business School,

Monash University

900 Dandenong Road

Caulfield East, Victoria 3145

Australia

Email: dennis.petrie@monash.edu

Sarah Smith

Department of Economics

University of Bristol

8 Woodland Road

BS8 1TN

United Kingdom

Email: sarah.smith@bristol.ac.uk 


\title{
Highlights
}

- An adverse health shock does not lead to a general increase in pro-social behaviour, measured by donations to charity.

- However, there is a change in the type of charities donated to by existing donors who add health charities to their giving portfolio.

- There is an accompanying increase in amounts given to health charities at the expense of non-health, non-religious charities.

- Giving to health charities is greatest in the year after the health shock and attenuates thereafter.

\begin{abstract}
'Altruism born of suffering' (ABS) predicts that, following an adverse life event such as a health shock, individuals may become motivated to act pro-socially. However, this has not yet been examined systematically. Using data from the United States Panel Study of Income Dynamics, we find that a health shock does not lead to a general increase in pro-social behaviour. Instead, ABS is akin to a specific shock that affects giving to health charities, with an increase in the probability of giving and amounts donated to health charities coming at the expense of other non-religious charities.
\end{abstract}

\section{Keywords}

Altruism born of suffering; charitable giving; pro-social behaviour; health shock; warm glow

\section{Funding sources}

This research did not receive any specific grant from funding agencies in the public, commercial, or not-for-profit sectors. 


\section{Altruism born of suffering? The impact of an adverse health shock on pro-social behaviour}

\section{Introduction}

"With more and more people affected by cancer every day, I believe we are in a world desperate for healing, and I'm committed to doing whatever I can to help."

Olivia Newton-John (Olivia Newton-John Cancer Wellness \& Research Centre, 2019)

Actress and singer, Olivia Newton-John, most famous for her role in the film Grease, was diagnosed with breast cancer in 1992 and subsequently became an advocate for cancer research and prevention. She donated the proceeds from various album sales to benefit breast cancer research, volunteered to lead fundraising activities and prevention campaigns, and helped to raise funds for public health services. Her pro-social behaviour ${ }^{1}$ and generosity following a major health event has been held up as example of what social psychologists refer to as 'altruism born of suffering' (ABS), which describes how individuals who have suffered may become particularly motivated to help others - not only despite their difficult experiences but precisely because of them (Staub, 2003, Staub, 2005, Staub and Vollhardt, 2008, Vollhardt and Staub, 2011). This phenomenon has been reported to encompass a range of pro-social behaviours such as donating blood, helping others and activism; and different types of adverse health events such as stroke and heart attack (Vollhardt and Staub, 2011). However, despite anecdotal support for ABS, the effect of an adverse health shock on pro-social behaviour has not been examined systematically. This paper addresses that gap.

\footnotetext{
${ }^{1}$ Defined as voluntary contributions to public goods (Gneezy et al., 2011)
} 
We present new evidence on the effect of adverse health shocks on pro-social behaviour using data from the United States (US) Panel Survey of Income Dynamics (PSID) from 2001 - 2015. We follow previous studies in defining an adverse health shock as an unanticipated change in health through a new diagnosis of a potentially life-threatening condition, namely cancer, heart attack or stroke (Jones et al., 2016, Smith et al., 2001). ${ }^{2}$ We focus on charitable giving as the key pro-social behaviour of interest. Charitable giving is widespread in the US, with an estimated 70 per cent of households giving to charity each year, and these donations play an important role in the private provision of public goods ${ }^{3}$. We explore the effect of an adverse health shock on overall giving and on giving to different charity types (separating health, religious and other non-health causes). We look both at the extensive margin (whether or not people give) and the intensive margin (how much people give). We also carefully examine the timing of charitable giving in relation to the health shock to provide insights into the dynamic nature of pro-social behaviour following a health shock. We use the rich set of variables available in the PSID to control for a wide range of mediating influences in our analysis.

Adverse health shocks are associated with poorer health status, reduced income and increased healthcare expenditure, although we find no effect on religiosity. We find that, following an adverse health shock, there is no change in the probability of donating to a charity overall, nor is there any increase in total giving. However, there is a change in the type of charities to which people give. There is a significant increase in the probability of giving to health charities with no change in the probability of donating to religious or other non-health charities. This indicates that existing donors add health charities to their charity portfolio. Effects on amounts given are

\footnotetext{
2 These studies focus on these conditions because they occur suddenly and largely unexpectedly, and are regarded as 'unanticipated' because the exact timing of onset is unknown. So, while risk factors may inform an individual about their health risks, it remains largely uninformative with respect to the timing of the event. ${ }^{3}$ Charitable giving totalled around US $\$ 410$ billion in 2017 , with $70 \%$ of giving coming from individuals (Giving USA, 2018)
} 
imprecisely estimated but donors give more to health charities and less to other, non-health charities. The effect on religious giving is positive but insignificant.

We find important dynamic effects. The impact of the adverse health shock is greatest in the year immediately after the health shock - the probability of donating to health charities is 11 percentage points above the baseline rate of around 30\%; it attenuates thereafter, but the probability of donating to health charities remains higher - and is 6 percentage points above baseline - more than one year after the health shock.

We find that neither income, health expenditure, religiosity nor health status appears to influence the relationship between the health shock and pro-social behaviour. This implies that the health shock itself appears to be directly influencing charitable giving and that there is limited mediation through the pathways of income, healthcare expenditure, health status and religiosity.

These findings provide important insights into the nature of 'altruism born of suffering'. In our study, an adverse health shock does not lead to a general increase in pro-social behaviour; it neither causes people to start giving, nor does it spark an increase in donations across charitable causes. Instead, altruism born of suffering is akin to a specific shock that affects giving to health charities. There are several possible causes for this: people experiencing an adverse health shock may gain insights into the need for healthcare services, they may experience feelings of reciprocity, they may also have a greater degree of sympathy towards people with similar conditions and want to help a newly-formed ingroup.

We interpret the observed patterns as arising from an increase in the salience of a specific charitable cause, similar to the effect of a charity fundraising appeal examined by Scharf et al (2017). Their paper investigated the effect of major disaster appeals which were found to cause a lift in total donations and a shift in the share of giving going to different causes, but no overall 
decline in other charities. In our case, we find no overall lift but only a shift in the level of donations to health charities away from other, non-health charities.

This paper bridges existing literatures in social psychology and economics. There is a substantial economics literature on the consequences of adverse health shocks (e.g. GarciaGomez, 2011, Liu, 2016, Lindeboom et al., 2016). We build on this literature and follow existing studies in how we define adverse health shocks; we add to it by studying the impact of health shocks on an outcome that has previously received little attention, i.e. pro-social behaviour. There is a literature outside economics that investigates pro-social behaviour following adverse life events (e.g. Reeves et al., 1999, Gillen, 2005) but, to date, it has been largely qualitative and it remains unclear as to whether the self-reported altruistic intentions in these studies ultimately translates into action; we add to it by providing quantitative evidence on the impact of adverse health shocks and we focus on a widespread pro-social action, namely charitable giving. We also contribute to a large literature on philanthropy that has investigated the effect of different demographic and socio-economic characteristics on charitable giving (summarised in Bekkers and Wiepking, 2011, Wiepking and Bekkers, 2012); we add to this by providing new evidence on a determinant of giving that has not previously been considered. We therefore offer further understanding of the determinants of giving that can inform charity fundraising strategies.

The finding that the effect of adverse health shocks varies between the immediate aftermath and longer-term reinforces the findings from recent studies that it is important to move beyond static analyses to consider the dynamics of charitable giving over time (Andreoni and SerraGarcia, 2018, Scharf et al., 2017, Rooney et al., 2019); by showing an increase in giving to health charities occurs at the expense of giving to non-health charities, we also add to a growing number of papers that provide evidence on substitutability / complementarity between different types of giving (Reinstein, 2011, Harwell et al., 2015, Filiz-Ozbay and Uler, 2018). 
The rest of the paper is structured as follows. Section 2 discusses how a health shock might affect giving - and summarises the hypotheses to be investigated. Section 3 outlines the data. Section 4 outlines the methodology. Section 5 presents the main results. Section 6 presents a discussion of the findings, implications, limitations and concludes.

\section{Health shocks and donations}

In this section we discuss ways in which a health shock might impact on charitable giving - focusing on individuals' total giving, their giving to different charities and their giving over time.

\subsection{The impact of a health shock}

The economics literature identifies altruistic reasons for giving, i.e. people give because they care about the total amount of public good that is provided, and warm glow (or impure altruism) reasons, i.e. people give because they experience utility from their own contributions, for example feeling good about giving, fulfilling a sense of duty, reducing a sense of guilt or enhancing their reputation or status (Meier, 2006). Some models combine elements of both. In a model of impure altruism with conditional altruism, warm glow is conditional on motives such as need, deservingness and reciprocity (Konow, 2010, Fong, 2007). Atkinson (2009) proposes a model of 'identification' in which utility depends on the donors' sympathy with recipients and the extent to which donors perceive that their donation will have an impact on the wellbeing of the identified recipients. These identified recipients are typically a subset of those for whom the donors can imagine will benefit (this is reinforced by the way charities advertise).

In the social psychology literature, 'altruism born of suffering' posits that, following an adverse life event, people undergo a range of experiences and psychological processes that might increase pro-social behaviour. This includes greater awareness of suffering; increased 
perspective-taking; empathy and sympathy; perceived similarity and identification with common-fate groups or ingroups; and a greater sense of responsibility to prevent others' suffering (Staub and Vollhardt, 2008, Vollhardt, 2009). These changes could increase either altruistic or warm-glow giving. They may trigger altruistic giving by making public services more salient or by changing beliefs about the public good benefits from such services. These changes may apply to public services in general or health services in particular. For example, following an individual's diagnosis of a rare cancer, the individual may become more aware of the lack of resources and knowledge regarding the cancer relative to what they knew before their diagnosis. The changes may also trigger warm glow giving by increasing the degree of sympathy that donors have towards others. This could be towards other people in general (increasing total giving) or focused on a specific (newly-formed) ingroup who share their health condition with whom they may now feel a deeper connection; individuals' may also be motivated by reciprocity and the desire to give back (Meier, 2006, Konow, 2010, Fong, 2007).

Although 'altruism born of suffering' suggests an increase in giving, it is possible that a health shock triggers psychological processes that reduce charitable giving - people experiencing a health shock may perceive themselves to be worse off than others and thus worthy of receiving rather than giving support. While Lim and DeSteno (2016) found this to be the case in the immediate aftermath of adversity more generally, there may be enduring physical and psychological problems following a health shock (e.g. Jansen et al., 2010) so the effect may be ongoing. People may also become antisocial following a health shock as they attempt to come to terms with their diagnosis and prognosis. For example, some studies have reported intentional unsafe sex among HIV-positive men (e.g. Halkitis and Parsons, 2003); however, this literature acknowledges that this constitutes the actions of the minority.

Increased religiosity may provide an indirect channel through which charitable giving may increase following a health shock. Religious giving is an important component of overall giving 
in the US (Giving USA, 2018). Individuals may turn (more) to religion following a health shock given that it can be a form of coping, source of support and stress deterrent (Siegel et al., 2001, Pargament and Hahn, 1986, Tix and Frazier, 1998). Increased engagement with religious services may lead to an increase in donations to the individual's local place of worship or, because religion discusses the suffering of others and emphasises the importance of helping others, more generally to a range of charitable and needy causes. In the empirical analysis below, we differentiate religious charities from other non-health charities as these may be differentially impacted.

\subsection{The effect on donations}

This discussion suggests a range of ways in which a health shock might impact giving. Scharf et al. (2017) provide a framework that can be used to think through these channels more formally. They introduce a (two-charity, two-period) "lift-shift model" to analyse the effects of fundraising campaign on total donations ("lift") and on donations to different charitable causes ("shift") and over time. The model focuses on warm glow giving. Donors are assumed to derive warm glow $\omega$ from money donations (in \$) to health (h) and non-health (n) charities. "Salience parameters", $\alpha_{h t}$ and $\alpha_{n t}$, determine the extent to which donations to health and nonhealth charities at time $t$ produce warm glow i.e. $\omega_{h t}=\alpha_{h t} h_{t}$ and $\omega_{n t}=\alpha_{n t} n_{t}$. These salience parameters capture things like the degree of sympathy that donors have towards recipients or the sense of guilt from not giving. The price of warm glow from donations to health/ non-health is $1 / \omega_{h}$ and $1 / \omega_{n}$ : an increase in salience reduces the dollar price of warm glow (effectively a \$1 donation yields more warm glow).

A health shock may have a general (positive or negative) effect on salience (i.e. $\Delta \uparrow \alpha_{h t}$ and $\Delta \uparrow$ $\alpha_{n t}$ or $\Delta \downarrow \alpha_{h t}$ and $\left.\Delta \downarrow \alpha_{n t}\right)$. This would be the case if there was an increase in the degree of sympathy towards all others or if the individual became preoccupied by their own 
circumstances at the expense of sympathy for others. In both of these cases the (direction of) change in giving would be similar across all charities; giving would go up or down at the expense of other consumption. Note that these changes could be on the extensive margin (i.e. causing people to start or stop giving) and/or the intensive margin.

Alternatively, the health shock may increase salience of giving to health charities only (i.e. $\left.\Delta \uparrow \alpha_{h t}\right)$. In this case, giving to health charities would go up, but what happens to giving to non-health charities depends on the degree of substitution between warm glow from different charities and on the elasticity of substitution between aggregate warm glow and other consumption. An increase in giving to health charities may come at the expense of giving to non-health charities, but giving to non-health charities will not necessarily go down if the increased giving to health charities comes at the expense of other consumption. In the empirical analysis below, we differentiate religious charities from other non-health charities as these may be differentially impacted.

Recent studies have drawn attention to the importance of studying the dynamics of charitable giving (Andreoni and Serra-Garcia, 2018, Scharf et al., 2017, Rooney et al., 2019). Models of pure and impure altruism typically assume that individuals exhibit stable behaviour over time (Andreoni, 1990) but the fact that altruistic/ warm glow preferences may change following a health shock would be evidence that this is not the case. Some experimental studies have found that pro-social behaviour erodes with repetition (Dawes and Thaler, 1988); others that the effects of major fundraising campaigns fade over time (Scharf et al., 2017, Adena and Huck, 2019). The increase in salience may be temporary in which case another "shift" in giving may occur, namely from later periods to the immediate aftermath period after the health shock.

Finally, an adverse health shock could affect giving through the channels of reduced income and increased healthcare expenditure. Any decline in physical or mental health could impact 
labour force participation and income (Jones et al., 2016, Garcia-Gomez, 2011), and there may be an increase in healthcare expenditure due to out-of-pocket costs associated with ongoing care and treatment such as specialist consultations, diagnostic scans and medication (Narang and Nicholas, 2017, Paez et al., 2009). There may also be an increase in uncertainty about future income which increases precautionary saving at the expense of all spending. We control for these other factors in our analysis.

This discussion shapes the empirical questions that we investigate:

- Is there a change in charitable giving after a health shock? If so, is the change on the extensive margin (i.e. whether people give) or on the intensive margin (amount of giving)?

- Do changes in giving vary across different charitable causes (specifically, health, religious and other non-health)?

- Are any changes permanent or do they fade over time?

- To what extent can changes in giving be attributable directly to the health shock as opposed to other mediating factors (income, spending needs, religiosity)?

We turn now to our empirical analysis, beginning with discussion of the data.

\section{Data}

\subsection{Panel Study of Income Dynamics (PSID)}

The PSID is a survey of a nationally representative panel of households in the United States, which began in 1968, containing detailed information on economic, health and social issues. From 2001 to 2015 biennially, the PSID contains a philanthropy module comprising a series of detailed questions relating to charitable giving. Due to the focus on charitable giving, the analysis will be restricted to this period. Our sample consists of households of 'couples' 
(with or without other household members) where one member of the couple experienced a health shock from 2001 onwards. Because we estimate a within-household analysis and compare households' charitable giving after they experience a health shock with their behaviour prior to a health shock, we only include households who experience a health shock. Households are excluded if there were changes in the household head or spouse (e.g. due to death) to ensure that household composition remains constant, and if the health shock was not the first health shock (defined as multiple health shocks observed between 1999 to $2015^{4}$ ) to capture initial changes to charitable giving following an initial adverse health event. ${ }^{5}$ The final sample comprises 3,133 observations on 452 households.

Table 1 outlines the summary statistics of the key variables used as time varying controls in the analysis. The mean age of the household head and partner is 56 and 54 respectively, with a mean household size of 3.0 and household equivalised income of around $\$ 65,000$. We also control for other significant events such as the birth or death of a child (a relatively uncommon occurrence), and the presence of an unrelated health condition (69\%) which may influence salience of need towards the health sector.

Table 1: Summary statistics of control variables (2001-2015)

\begin{tabular}{lcc}
\hline & Mean & SD \\
\hline Demographics & & \\
Age - head & 56.0 & 11.2 \\
Age - partner & 53.6 & 11.0 \\
Household characteristics & & \\
Household size & 3.0 & 1.3 \\
Annual household equivalised income (real 2015, USD ‘000) & 64.7 & 99.5 \\
Number of children & 0.6 & 1.0 \\
Death of child (=1 if death of child occurred \%) & 0.2 & 4.0 \\
Birth of child (=1 if birth of child occurred \%) & 3.0 & 17.0 \\
Other unrelated health condition (=1 if has asthma or arthritis \%)* & 69.0 & 46.0 \\
\hline Observations & 3,170 & \\
\hline Note: Asthma and arthritis wer selected & & \\
\hline
\end{tabular}

Note: Asthma and arthritis were selected based on data availability.

\footnotetext{
${ }^{4}$ Data on health conditions are available from 1999 to 2015 in comparison to data on charitable giving which is available from 2001 to 2015 .

${ }^{5}$ Changes in household composition and multiple health shocks are later included in the sample when robustness checks are undertaken.
} 


\subsection{Charitable giving}

Households are asked whether they donated to a charitable organisation and if so, are asked to indicate the total dollar value of donations in the calendar year prior to the survey wave. ${ }^{6}$ Both questions are asked for each of the following charity sectors: health, religious, combination, needy, education, youth, cultural, community, environment, international peace and other. In this paper, we focus on the health and religious charity sectors and combine all other sectors to form an 'other' category. ${ }^{7}$

The mean probability of donating to a charity across all households in all years is $82 \%$. Figure 1 shows that by sector, more households donate to a religious charity $(62 \%)$ and other charities (65\%), compared to health (32\%). The distribution of total donations is positively skewed with a number of outliers. Figure 1 also shows that in terms of mean donations per annum, the religious sector receives the highest donations $(\$ 2,057)$ compared to health $(\$ 127)$ and other (\$937).

\footnotetext{
${ }^{6}$ For example, in the 2001 PSID wave, households are asked about charitable giving during 2000.

${ }^{7}$ Health charities are defined as healthcare or medical research organisations such as hospitals, mental health facilities, cancer, heart and lung associations. Religious charities are defined as donations specifically for religious purposes or spiritual development such as churches, mosques or radio ministries.
} 
Figure 1: Average probability of households donating (2001-2015) and value of donations (in 2015 USD), by sector

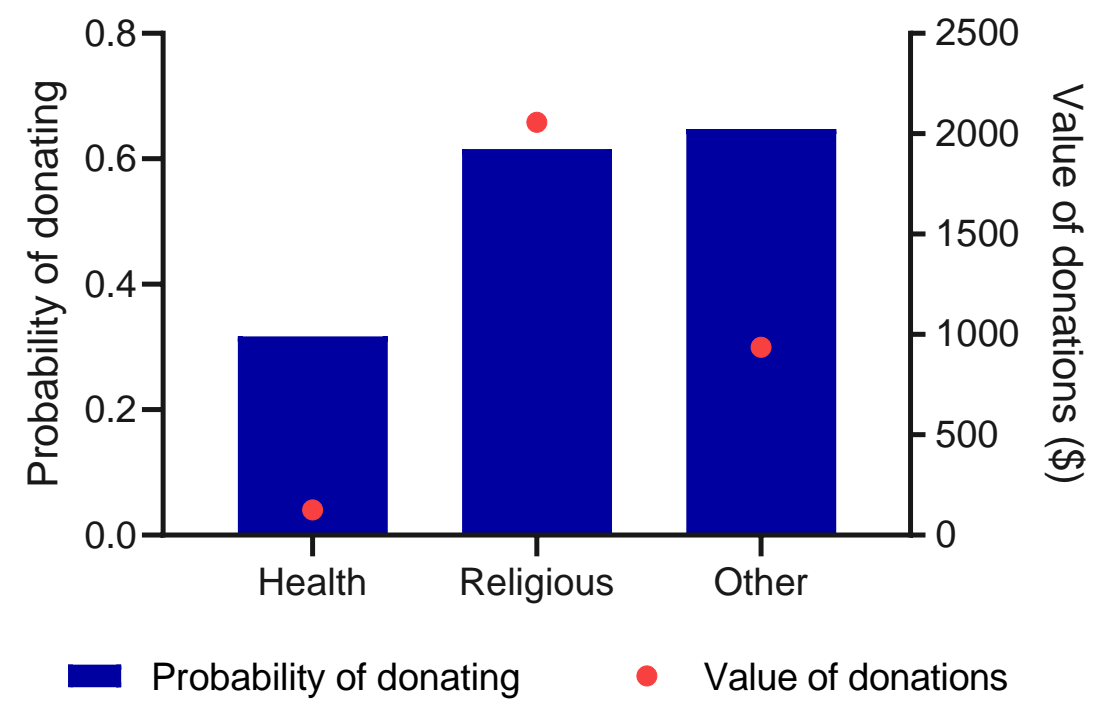

Note: Value of donations are in real 2015 USD, based on Consumer Price Index data from World Bank (2019).

\subsection{Health shocks}

Information on health conditions and events are available every two years from 19992015. Household heads are asked: "has a doctor ever told you that you have had a stroke [heart attack, cancer]?". In terms of the time since health shock, from 1999-2003, household heads are asked: "how long have you had this condition?". This differed from 2005-2015, and household heads are instead asked: "how old were you the first time you had a stroke [heart attack, cancer]?" and "have you had another stroke [heart attack] at any time in the past 12 months/a second or subsequent stroke [heart attack] since that first one?" All questions were also asked for spouses. In our sample, of those who experienced a health shock, $62 \%$ had cancer, $23 \%$ had a heart attack and $15 \%$ had a stroke.

From these questions, we combine health information on the household head and their spouse to construct two key household health shock variables: (1) whether a household head or spouse had a health shock, and (2) the time since the health shock (relative to when donations were 
made). For 1999-2003, time since the health shock is taken directly from the question: "how long have you had this condition?". For 2005-2015, time since health shock is calculated as the difference between the household head/spouse's age at the interview date and the age they reported they first had the condition. We then use the time since health shock to calculate the key variable: (3) the date of the health shock. Time of the donations relative to the health shock is then grouped into six categories:

(1) $\mathrm{t}<-2$ : more than two calendar years prior to the health shock;

(2) $t=-2$ : in the calendar year two years prior to the health shock;

(3) $t=-1$ : in the calendar year prior to the health shock;

(4) $t=0$ : in the calendar year of the health shock;

(5) $t=1$ : in the calendar year following the health shock; and,

(6) $t>1$ : more than one calendar year following the health shock.

An example of how these timing flags are constructed is illustrated in Figure 2, where the survey wave corresponds to the donation period in the previous calendar year. Panel A provides an example of a health shock that occurred in 2006. This health shock gets reported in the 2007 survey wave, along with the household's donations for the 2006 calendar year. Hence, this period is categorised as $t=0$ given that donations occur in the same calendar year as the health shock. The remainder of the timing flags are outlined in Panel A in accordance to the time of donations relative to the health shock in 2006. Panel B provides an example of a health shock that occurred in 2007. This health shock also gets reported in the 2007 survey wave; however, the donation period for the 2006 calendar year corresponds to the year prior to the health shock, so this period is categorised as $\mathrm{t}=-1$.

Given that donations are reported for the previous calendar year, there are two potential scenarios at $\mathrm{t}=-1$. The first is that a household may report on their donations in the calendar 
year prior to the health shock year (donations for $\mathrm{t}=-1$ ) before their health shock in the current survey year has happened (we only find out they had a health shock in later waves) (Case 1 in Figure 2, Panel C). The second is that a household may report on their donations in the calendar year prior to the health shock year (donations for $\mathrm{t}=-1$ ) after the health shock has already happened in the current survey year (Case 2 in Figure 2, Panel C). For example, in the 2007 wave an individual may report on their 2007 health shock while also reporting on their 2006 calendar year donations. This may result in reporting bias where those who had their survey after the health shock may inflate their reported donations (i.e. Case 2, Panel C) - they may donate more following their health shock and feel compelled to inflate their 2006 donations to include these recent donations. We account for this by including an interaction term which captures whether the interview date was before or after the health shock at $\mathrm{t}=-1$.

Further details on the construction of these timing flags is provided in Supplement B. 
Figure 2: Construction of timing flags - example

\begin{tabular}{|c|c|c|c|c|c|c|c|c|}
\hline $\begin{array}{l}\text { Donation period } \\
\text { corresponds to } \\
\text { Survey wave }\end{array}$ & 2001 & 2003 & 2005 & 2007 & 2009 & 2011 & 2013 & 2015 \\
\hline \multirow[t]{2}{*}{ A. Health shock in 2006} & $\mathrm{t}<-2$ & $t<-2$ & $t=-2$ & $\mathrm{t}=0$ & $\mathrm{t}>1$ & $\mathrm{t}>1$ & $t>1$ & $\mathrm{t}>1$ \\
\hline & \multicolumn{2}{|c|}{$\begin{array}{l}\text { Donations for } 2000 \text { and } 2002 \text { occurred } \\
\text { more than } 2 \text { years before the health } \\
\text { shock. }\end{array}$} & $\begin{array}{l}\text { Donations for } 2004 \\
\text { occurred } \sim 2 \text { years } \\
\text { before the health } \\
\text { shock. }\end{array}$ & $\begin{array}{l}\text { Household reports } \\
\text { donations for } 2006 \\
\text { during } 2007 \\
\text { survey wave. This } \\
\text { period (2006) } \\
\text { coincides with the } \\
\text { year of the health } \\
\text { shock. }\end{array}$ & \multicolumn{4}{|c|}{ Donations during these periods occurred more than 1 year following the health shock. } \\
\hline \multirow[t]{2}{*}{ B. Health shock in 2007} & $t<-2$ & $\mathrm{t}<-2$ & $t<-2$ & $t=-1$ & $t=1$ & $t>1$ & $t>1$ & $t>1$ \\
\hline & \multicolumn{3}{|c|}{$\begin{array}{l}\text { Donations during these periods occurred more than } 2 \text { years } \\
\text { before the health shock. }\end{array}$} & $\begin{array}{l}\text { Household reports } \\
\text { donations for } 2006 \\
\text { during } 2007 \\
\text { survey wave. This } \\
\text { period (2006) } \\
\text { corresponds to } 1 \\
\text { year before the } \\
\text { health shock. }\end{array}$ & $\begin{array}{l}\text { Donations for } 2008 \\
\text { occurred } \sim 1 \text { year } \\
\text { after the health } \\
\text { shock }\end{array}$ & \multicolumn{3}{|c|}{$\begin{array}{l}\text { Donations during these periods occurred more than } 1 \text { year } \\
\text { following the health shock. }\end{array}$} \\
\hline \multicolumn{9}{|l|}{ C. Interaction term at $t=-1$} \\
\hline \multicolumn{9}{|l|}{$\begin{array}{l}\text { Case 1: interview date } \\
\text { (March 2007) occurred } \\
\text { before health shock }\end{array}$} \\
\hline $\begin{array}{l}\text { - Case 2: interview date } \\
\text { (September 2007) occurred } \\
\text { after health shock }\end{array}$ & & & & $=1$ & & & & \\
\hline
\end{tabular}




\section{Empirical strategy}

We estimate the following empirical model:

$Y_{i t}=\sum_{n=-2}^{n=2} \beta_{n} H S_{i t+n}+X^{\prime}{ }_{i t} \gamma+\alpha_{i}+\lambda_{s}+\varepsilon_{i t}$

where $Y_{i t}$ is the outcome of interest for household $i$ at time $t$. In different specifications, this is defined as the probability of donating and the value of donations, both overall and by sector (health, religious or other). ${ }^{8}$

We include a set of indicators, $H S_{i t+n}$, for when charitable giving in a particular calendar year occurred in relation to the health shock. In particular, we consider six different time periods: $t<-2$ (more than two years prior to the health shock); $t=-2$ (one to two years prior to the health shock); $t=-1$ (up to one year prior to the health shock); $t=0$ (same year as the health shock); $t=1$ (up to one year following the health shock); and $t>1$ (more than one year following the health shock). The reference category is $t<-2$, so our model compares household donation behaviours relative to their own behaviour more than two years prior to the health shock.

In addition, $\alpha_{i}$ are household fixed effects, $\lambda_{s}$ are survey year fixed effects and $\varepsilon_{i t}$ is an error term. $X^{\prime}$ is a vector of time varying control variables affecting charitable giving which includes age, household size, presence of an unrelated health condition and a life event such as the birth or death of a child (as discussed in Section 3.1). It also includes a control for whether a household was reporting on their pre-shock donations after their health shock in order to minimise reporting bias (as discussed in Section 0).

The distribution of our donations data is strongly skewed, with a heavy right-hand tail and a

\footnotetext{
${ }^{8}$ In Equation (1) we provide a linear specification though in some models examining the value of donations for particular sectors a linear-log specification is estimated.
} 
relatively large number of zeros. To estimate the impact of a health shock on the value of donations, we consider generalised linear models (GLMs) with fixed effects and alternative links and family distributions and select our preferred specification based on model performance (specification tests and goodness of fit). Values are winsorised at the $5^{\text {th }}$ and $95^{\text {th }}$ percentile to reduce the impact of outliers. Where the log link is used, zero donations are recoded as $\$ 1$. Where the preferred specification has a log link, robustness tests are undertaken for changes in recoding to $\$ 0.10$ and $\$ 0.01$. Our preferred specification for health sector donations is a linear link with Gaussian (normal) distribution, while for total, religious and other sector donations, the log link and gamma family distribution are preferred. ${ }^{9}$ We also report on the second preferred specification to explore the robustness of our conclusions.

Because health status, income, healthcare expenditure and religiosity are potential mechanisms through which a health shock could influence charitable giving, we investigate these characteristics further in two ways. First, we estimate the extent to which health status (of the household member experiencing the health shock), household income and religiosity (household frequency of attendance at religious services) are impacted by a health shock. Second, we include them in the main model (1) as covariates and see how they change the estimated impact of the health shock on giving behaviour. In terms of the extent to which they are impacted by a health shock, the impact on health status is estimated using a fixed effects ordered logit Blow-Up and Cluster Estimator (BUC) for self-assessed health status (Baetschmann and Staub, 2015), ${ }^{10}$ and the impacts on income, healthcare expenditure and

\footnotetext{
${ }^{9}$ We undertake a Link test to determine the appropriate link function (we test the log, square root and linear link). The modified Park test is undertaken to select an appropriate distributional family. Where multiple specifications or distributional families were not rejected, we chose the model on the basis of lower root mean square standard error and mean average prediction error, similar to the approach in Jones (2011). As a robustness check, we undertake a comparison with the next best alternative model (linear link with Gaussian distribution for religious, other and total donations, and log link inverse gaussian for health donations).

${ }^{10}$ When estimating fixed effects ordered logit models such as for self-assessed health status, there are issues associated with unobserved heterogeneity which can result from omitted variables or subjective differences in the anchoring of responses on the ordered response scale. If unaccounted for, heterogeneity will generally bias
} 
religiosity are estimated using standard linear fixed effects models.

\section{Results}

\subsection{How are health status, income, healthcare expenditure and religiosity impacted by a health shock?}

To provide an understanding of the various impacts to the household following a health shock, in Figure 3 we present estimates of the impact of a health shock on changes in health status (of the household member experiencing the health shock), household equivalised income and religiosity of the household. Panel A shows that compared with more than two years prior to the health shock $(\mathrm{t}<-2)$, there is a significant worsening of self-assessed health in the year of the health shock ( $t=0)$ and in the years following the health shock ( $t=1$ and $t>1)$. Importantly, these estimates suggest that the individual is indeed experiencing a health shock, with noticeable changes to their health status during the year of and after the heath shock.

Panel B of Figure 3 shows that compared to $t<-2$, household income reduces at all time periods, though these are generally not statistically significant. An exception is at $t=1$ (one year following the health shock), where there is a significant and large reduction in household income of around $\$ 10,177$. This suggests a temporary reduction in employment in the year following the health shock. Additional analyses using data on self-reported healthcare expenditure suggests that these income changes occur alongside a significant increase in healthcare expenditure by around $\$ 1,324(\mathrm{p}<0.05)$ and $\$ 1,127(\mathrm{p}<0.05)$ at $\mathrm{t}=1$ and $\mathrm{t}>1$ respectively (Panel C). Combined, this suggests that following a health shock, households are likely to have less disposable income to give to charities. 
In Panel D of Figure 2, we show that a health shock has statistically insignificant effects on religiosity (measured by frequency of attendance at religious services) across all time periods. It is therefore unlikely that changes in religiosity play a major role in influencing the decision to donate following a health shock. Religious preference (i.e. whether an individual identified themselves with a religion) did not change over time so could not be examined in our fixed effects models. All coefficient estimates are provided in Table A1 (Supplement A). 
Figure 3: Impact of a health shock on health status, income, healthcare expenditure and religiosity (potential mediators)

(A) Health status

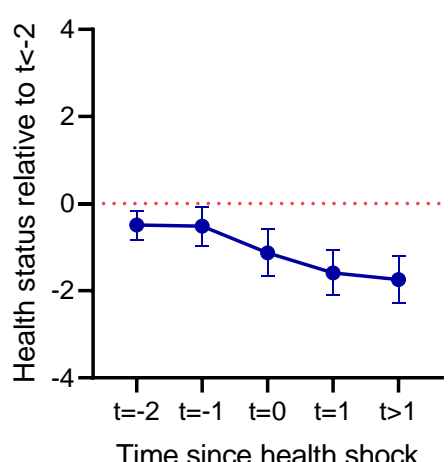

(B) Income (\$)

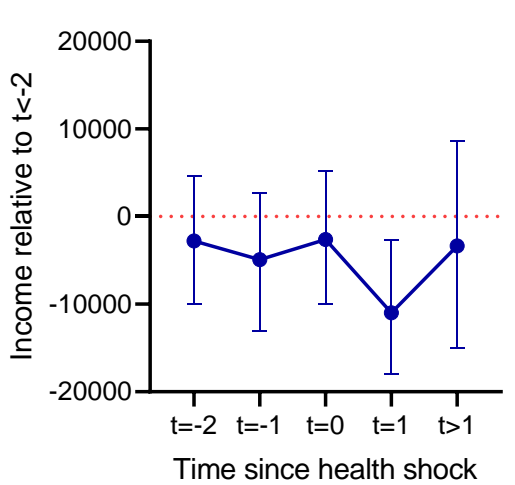

(C) Healthcare expenditure (\$)

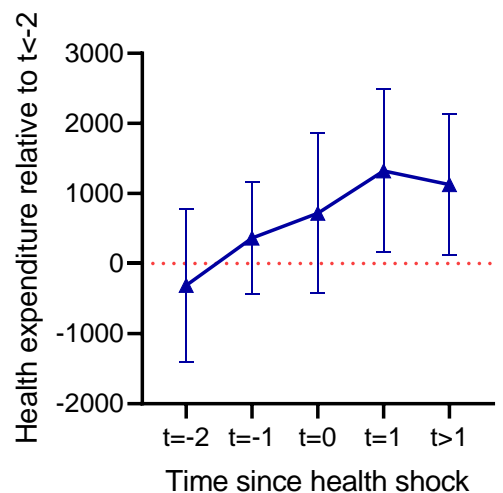

(D) Religiosity

Frequency of attendance at religious services

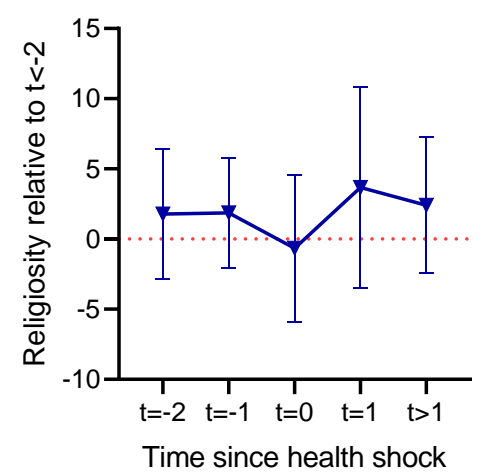

Sample: couples households present in sample from 2001 onwards who experience no changes in couple household composition following a first health shock. Error bars are 95\% confidence intervals based on cluster-robust standard errors.

Reference category is more than two years prior to the health shock $(\mathrm{t}<-2)$

(A) Fixed effects ordered logit Blow-Up and Cluster Estimator (Baetschmann and Staub, 2015) for self-assessed health status. 1,194 individuals (8,057 observations) with a health shock dropped because of all the same outcomes. Self-reported health status of the household member who experienced the health shock, measured on a scale of 1 to 5 where a lower value corresponds to poorer health: (1) poor; (2) fair; (3) good; (4) very good; (5) excellent.

(B) Fixed effects estimates of time relative to health shock and household equivalised income (\$). Based on 3,134 observations of 452 unique households.

(C) Fixed effects estimates of time relative to health shock and healthcare expenditure (\$). Based on 3,134 observations of 452 unique households.

(D) Fixed effects estimates of time relative to health shock and household frequency of attendance at religious services (number of times of attendance per year). Data is only available for the years 2003, 2005 and 2011. Based on 1,224 observations of 442 unique households. There are no changes in religious preference in the sample, so this is not shown.

All models include as covariates: age of head and partner, family unit size, death of child, new birth in household, other unrelated health condition (asthma, arthritis) and time (year) dummies.

Models (B), (C) and (D) additionally include an indicator of whether they were reporting on pre-shock donations after their health shock (interaction between whether had health shock condition and $\mathrm{t}=-1$ ).

Detailed results are provided in Supplement A (Table A1). 


\subsection{Dynamics of donating relative to a health shock - probability of donating}

In Figure 4, we show the dynamics of the probability of donating relative to the health shock. Panel A shows that there is no effect on the overall probability of donating. There is a small decrease in the probability of donating during and following a health shock, but these estimates are not significant.

While there is little impact on the overall probability of donating, Panel B of Figure 4 shows that there is a significant positive impact on the probability of donating to health charities. The greatest increase in the probability of donating to health charities occurred at $t=1$ by around $11 \%(\mathrm{p}<0.01)$, declining at $\mathrm{t}>1$ (more than a year following the health shock) although it still remains higher than $\mathrm{t}<-2$ (charitable giving more than two years prior to the health shock). There is also a small but insignificant change in the probability of donating to religious $(0.2 \%)$ and other sectors $(-3.1 \%)$ at $\mathrm{t}=1$ (Panel $\mathrm{C}$ and $\mathrm{D})$. When we break down the 'other' sectors into its respective categories (Table A3, Supplement A), coefficient estimates remain small and imprecisely estimated, ranging from $-5 \%(\mathrm{p}<0.10)$ for education to $4 \%(\mathrm{p}<0.10)$ for international peace. Further details are provided in Supplement A, Table A2.

The new givers to the health sector predominantly comprise households that donated to another (non-health) sector prior to their health shock (96\%), compared to those that did not donate at all (4\%). So, while there is no general increase in the proportion of those giving following an adverse health shock, existing donors appear to be adding health charities to their giving portfolio. We confirm this by estimating the number of sectors donated to as an outcome of the health shock. A fixed effects Poisson model indicates that the number of sectors donated to at $\mathrm{t}=1$ increases by a factor of 1.06 at $\mathrm{t}=1$ (further details are provided in Supplement A, Table A4). These results suggest that there may need to be a baseline level of charitable giving and altruism prior to the health shock for the response to occur. 
We also examine heterogeneity of these results by the type of health shock, prior health conditions and religiosity (further details in Supplement C). Different health shock conditions could elicit different responses given differences in population affected, treatment and prognosis. We find that cancer elicits the strongest response of all the health shocks conditions, with a significant increase in the probability of donating to health by $13 \%$ at $t=1(p<0.01)$ which remained at $\mathrm{t}>1(11 \%, \mathrm{p}<0.05)$ (Supplement C, Error! Reference source not found.). Prior to a health shock, an individual may have an already diagnosed health condition (e.g. diabetes, hypertension, asthma), so may already be salient towards the needs of the health sector. Our results indicate that these individuals had a significant increase in the probability of donating to health at $\mathrm{t}=1(13 \%, \mathrm{p}<0.01)$ and $\mathrm{t}>1(9 \%, \mathrm{p}<0.01)$ compared to those who did not, although their donation amounts suggest these are token (Supplement C, Table C6). Religiosity may also have an impact on charitable giving. We further investigate heterogeneity by whether the household was religious or not, where religiosity is defined as the frequency of attendance at religious services per annum. Regardless of our definition of 'religious' and 'non-religious' households, the results consistently showed that religious households are more responsive following a health shock with a higher probability of donating and value of donations across all sectors compared to non-religious households (Supplement C, Table C10-Table C13). This may be due to the greater level of baseline pro-social behaviour translating into a higher propensity for charitable giving following a health shock. 

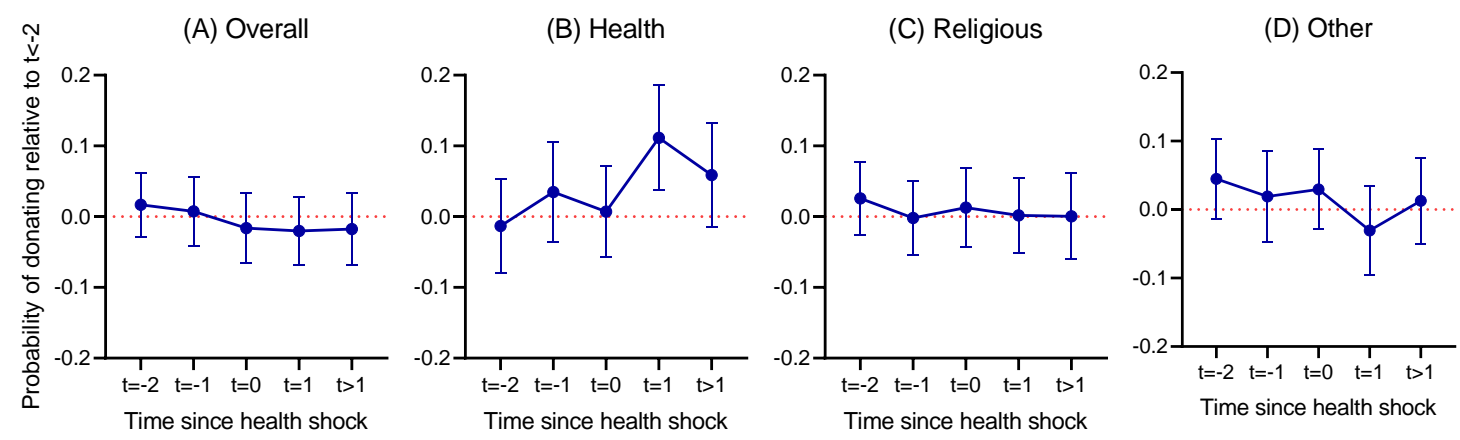

Fixed effects estimates of time relative to health shock and the probability of donating by charity sector. Reference category is more than two years prior to the health shock $(\mathrm{t}<-2)$.

All models include fixed effects and covariates: age of head and partner, family unit size, death of child, new birth in household, other unrelated health condition (asthma, arthritis), time (year) dummies, whether they were reporting on pre-shock donations after their health shock (interaction between whether had health shock condition and $\mathrm{t}=-1$ ).

Sample: couples households present in sample from 2001 onwards who experience no changes in couple household composition following a first health shock.

Error bars are $95 \%$ confidence intervals based on cluster-robust standard errors.

Detailed results are provided in Supplement A (Table A2).

\subsection{The roles of income, healthcare expenditure and health status}

In Table 2, we present estimates of our main model on the probability of donating to the health sector (shown in Panel B of Figure 4) with income, healthcare expenditure and health status included as additional control variables. Neither income, healthcare expenditure nor health status are statistically significant, and the coefficient of the time periods relative to the health shock change very little with the inclusion of income or health status in the model. This suggests that changes in income and health status have little influence on the effect of a health shock on charitable giving. As expected, we find that including religiosity (refer to Supplement C, Table C14) as a control variable makes little difference to the estimated health shock coefficients. This implies that the health shock itself appears to be directly influencing charitable giving and that there is limited mediation through the pathways of income, healthcare expenditure and health status. 
Table 2: Dynamics of donating relative to a health shock - impact of health status, income and healthcare expenditure (potential mediators)

\begin{tabular}{|c|c|c|c|c|c|}
\hline VARIABLES & Main model & $\begin{array}{l}\text { (2) } \mathrm{Ir} \\
\text { Health status } \\
\end{array}$ & $\begin{array}{l}\text { e mediator } \\
(3) \\
\text { Income }\end{array}$ & $\begin{array}{l}\text { model } \\
\text { Healthcare expenditure }\end{array}$ & $\begin{array}{l}(5) \\
\text { All mediators }\end{array}$ \\
\hline Time relative to health shock & & & & & \\
\hline $\begin{array}{l}\text { Reference category: } \mathrm{t}<-2 \\
\text { (more than } 2 \text { years prior) }\end{array}$ & - & - & - & - & - \\
\hline$t=-2$ ( 1 to 2 years prior $)$ & $\begin{array}{l}-0.013 \\
(0.034)\end{array}$ & $\begin{array}{l}-0.012 \\
(0.035)\end{array}$ & $\begin{array}{c}-0.013 \\
(0.034)\end{array}$ & $\begin{array}{c}-0.014 \\
(0.034)\end{array}$ & $\begin{array}{l}-0.013 \\
(0.035)\end{array}$ \\
\hline t=-1 (up to 1 year prior) & $\begin{array}{c}0.035 \\
(0.036)\end{array}$ & $\begin{array}{c}0.037 \\
(0.036)\end{array}$ & $\begin{array}{c}0.035 \\
(0.036)\end{array}$ & $\begin{array}{c}0.035 \\
(0.036)\end{array}$ & $\begin{array}{c}0.037 \\
(0.036)\end{array}$ \\
\hline $\mathrm{t}=0$ (year of health shock) & $\begin{array}{c}0.007 \\
(0.033)\end{array}$ & $\begin{array}{c}0.005 \\
(0.033)\end{array}$ & $\begin{array}{c}0.007 \\
(0.033)\end{array}$ & $\begin{array}{c}0.008 \\
(0.033)\end{array}$ & $\begin{array}{c}0.005 \\
(0.033)\end{array}$ \\
\hline $\mathrm{t}=1$ (up to 1 year after) & $\begin{array}{c}0.111 * * * \\
(0.038)\end{array}$ & $\begin{array}{c}0.116 * * * \\
(0.039)\end{array}$ & $\begin{array}{c}0.111 * * * \\
(0.038)\end{array}$ & $\begin{array}{c}0.113 * * * \\
(0.038)\end{array}$ & $\begin{array}{c}0.117 * * * \\
(0.039)\end{array}$ \\
\hline t>1 (more than 1 year after) & $\begin{array}{c}0.059 \\
(0.037)\end{array}$ & $\begin{array}{c}0.061 \\
(0.038)\end{array}$ & $\begin{array}{c}0.059 \\
(0.037)\end{array}$ & $\begin{array}{c}0.060 \\
(0.037)\end{array}$ & $\begin{array}{c}0.061 \\
(0.038)\end{array}$ \\
\hline $\begin{array}{l}\text { Potential mediators } \\
\text { Reference category: }\end{array}$ & & & & & \\
\hline Health status: poor & - & - & - & - & - \\
\hline Health status: fair & - & $\begin{array}{c}0.054 \\
(0.044)\end{array}$ & - & - & $\begin{array}{c}0.053 \\
(0.044)\end{array}$ \\
\hline Health status: good & - & $\begin{array}{c}0.027 \\
(0.047)\end{array}$ & - & - & $\begin{array}{c}0.026 \\
(0.047)\end{array}$ \\
\hline Health status: very good & - & $\begin{array}{c}0.063 \\
(0.051)\end{array}$ & - & - & $\begin{array}{c}0.061 \\
(0.051)\end{array}$ \\
\hline Health status: excellent & - & $\begin{array}{c}0.050 \\
(0.058)\end{array}$ & - & - & $\begin{array}{c}0.047 \\
(0.058)\end{array}$ \\
\hline Income $(10,000 \mathrm{~s})$ & - & & $\begin{array}{l}-0.001 \\
(0.001)\end{array}$ & - & $\begin{array}{c}-0.000 \\
(0.001)\end{array}$ \\
\hline Healthcare expenditure $(1,000 \mathrm{~s})$ & - & & & $\begin{array}{l}-0.001 \\
(0.001)\end{array}$ & $\begin{array}{c}-0.001 \\
(0.001)\end{array}$ \\
\hline Observations & 3,126 & 3,009 & 3,126 & 3,126 & 3,009 \\
\hline Unique households & 452 & 425 & 452 & 452 & 425 \\
\hline R-squared & 0.016 & 0.019 & 0.016 & 0.017 & 0.019 \\
\hline
\end{tabular}


Cluster-robust standard errors in parentheses

$* * * \mathrm{p}<0.01, * * \mathrm{p}<0.05, * \mathrm{p}<0.1$

Fixed effects estimates of time relative to health shock and probability of donating to health - impact of potential mediator(s) on the main model.

Reference category is more than two years prior to the health shock $(t<-2)$.

(1) Main model (as presented in Supplement A, Table A2).

(2) Main model with health status as a control variable.

(3) Main model with income $(10,000 \mathrm{~s})$ as a control variable.

(4) Main model with healthcare expenditure $(1,000 \mathrm{~s})$ as a control variable.

(5) Main model with health status, income (10,000s) and healthcare expenditure as control variables.

Religiosity is not shown given there were no changes in religious preference in the sample and frequency of attendance at religious services data was only available for 2003,

2005,2011 . When comparing the main model and the main model plus the frequency of attendance of religious service for 2003 , 2005 and 2011 , there were minimal changes

in the coefficients (Supplement C).

All models include as covariates: age of head and partner, family unit size, death of child, new birth in household, other unrelated health condition (asthma, arthritis), time

(year) dummies, whether they were reporting on pre-shock donations after their health shock (interaction between whether had health shock condition and $\mathrm{t}=-1$ )

Sample: couples households present in sample from 2001 onwards who experience no changes in couple household composition following a first health shock. 


\subsection{Dynamics of donating relative to a health shock - value of donations}

Table 3 presents the estimated marginal effects of time since a health shock on the value of donations. Column 1 presents the marginal effects of health donations using a GLM linear link and gaussian distribution, and Columns 2 to 4 present the marginal effects of religious, other and total donations. Zero donations are recoded to $\$ 1$ for religious, other and total donations. We winsorise the values (at the $5^{\text {th }}$ and $95^{\text {th }}$ percentile) to reduce the impact of outliers although the results remain imprecisely estimated.

There is no significant change in the total value of donations across all sectors (the negative coefficients are not statistically significant). In line with the increase in the probability of donating to health charities, there is an increase in the value of donations to health charities, albeit small $(\$ 24.27, \mathrm{p}<0.01)$. There is a larger increase in religious donations $(\$ 79.53)$ but this is statistically insignificant ( $\mathrm{p}>0.10)$. Donations to other sectors decreased at $\mathrm{t}=1(-\$ 140.38)$, significant at the 5\% level. Together, these results indicate that there is no "lift" in giving but instead a "shift" in donation dollars from other, non-health sectors into health and potentially religious sectors. These results are robust to including income, healthcare expenditure and health status as additional control variables (refer to Supplement A, Table A6).

Religious donations appear to be more stable across all time periods relative to the health shock, compared to health and other sectors which fluctuate between negative and positive estimates. Given historical trends in charitable giving to the religious sector, this may be reflective of the religious sector being viewed as a core component of a household's charitable giving budget, with health and other sectors viewed as subsidiary that can be adjusted at the margins.

While we do not find any evidence that religiosity is impacted by a health shock, the measures of religiosity in the PSID are limited to religious preference and frequency of attendance at religious services. Using different measures for religiosity, some studies have shown that the 
determinants of religious and secular giving differ and that religiosity plays a stronger role in religious giving (Brown 2007). Studies have also suggested that religion can be a mechanism of coping and support either during or in the immediate aftermath of the health shock (Siegel et al., 2001, Pargament and Hahn, 1986, Tix and Frazier, 1998), which may be reflected in the increase in religious sector donations at $\mathrm{t}<-1, \mathrm{t}=0$ and $\mathrm{t}=1$. Other reasons may include a desire to help out others more generally, or it could reflect a preference of the household to donate to the same charitable organisations it has undertaken due diligence on.

These results are robust to changes in the recoding of zero donations to $\$ 0.10$ and $\$ 0.01$, and using the next best alternative specified model (refer to Supplement A, Table A5). In addition, the results are also robust to expanding the sample to include multiple health shocks, changes in household composition (deaths), and including state of residence as a control variable (refer to Supplement C, Error! Reference source not found., Table C8 and Table C15). 
Table 3: Dynamics of donating relative to a health shock - value of donations (marginal effects), winsorised at the $5^{\text {th }}$ and $95^{\text {th }}$ percentile

\begin{tabular}{|c|c|c|c|c|}
\hline & \multicolumn{4}{|c|}{ Donations - marginal effects } \\
\hline & (1) & $(2)$ & $(3)$ & $(4)$ \\
\hline VARIABLES & Health $(\$)$ & Religious (\$) & Other $(\$)$ & Total $(\$)$ \\
\hline \multicolumn{5}{|l|}{$\begin{array}{l}\text { Time relative to health } \\
\text { shock }\end{array}$} \\
\hline $\begin{array}{l}\text { Reference category: } \mathrm{t}<-2 \\
\text { (more than } 2 \text { years prior) }\end{array}$ & - & - & - & - \\
\hline \multirow{2}{*}{$\mathrm{t}=-2$ ( 1 to 2 years prior $)$} & 4.28 & 107.11 & $119.50 *$ & 169.30 \\
\hline & $(5.49)$ & $(138.93)$ & $(62.28)$ & $(190.54)$ \\
\hline \multirow{2}{*}{$\mathrm{t}=-1$ (up to 1 year prior) } & 9.16 & 9.83 & 43.63 & $383.41 *$ \\
\hline & $(6.90)$ & $(142.78)$ & $(62.77)$ & $(216.74)$ \\
\hline \multirow[t]{2}{*}{$\mathrm{t}=0$ (year of health shock) } & 3.61 & 203.12 & -21.65 & 4.98 \\
\hline & $(5.50)$ & $(143.72)$ & $(58.03)$ & $(187.84)$ \\
\hline \multirow[t]{2}{*}{$\mathrm{t}=1$ (up to 1 year after) } & $24.27 * * *$ & 79.53 & $-140.38 * *$ & -76.92 \\
\hline & $(6.03)$ & $(137.46)$ & $(57.49)$ & $(191.99)$ \\
\hline \multirow[t]{2}{*}{$\mathrm{t}>1$ (more than 1 year after) } & $11.24 *$ & 81.71 & -76.27 & -203.74 \\
\hline & $(5.80)$ & $(152.02)$ & $(61.10)$ & (204.64) \\
\hline Observations & 3,098 & 3,096 & 3,130 & 3,130 \\
\hline Unique households & 452 & 452 & 452 & 452 \\
\hline
\end{tabular}

Cluster-robust standard errors in parentheses

$* * * \mathrm{p}<0.01, * * \mathrm{p}<0.05, * \mathrm{p}<0.1$

Marginal effects and within-households fixed effects estimates of time relative to health shock and donations by charity sector. Values winsorised at the $5^{\text {th }}$ and $95^{\text {th }}$ percentile to reduce the impact of outliers.

Reference category is more than two years prior to the health shock $(\mathrm{t}<-2)$.

(1) Health donations are estimated using GLM linear link and gaussian distribution.

(2) Religious donations are estimated using GLM log link and gamma distribution.

(3) Non-health donations are estimated using GLM log link and gamma distribution.

(4) Total donations are estimated using GLM log link and gamma distribution.

Marginal effects are shown in (1)-(4). Zero donations are recoded to $\$ 1$ which is robust to changes in recoding of zero donations to $\$ 0.10$ and $\$ 0.01$. Donations are winsorised (bottom and top 5\%). In addition, we compare results with the next best alternative model (log link with inverse gaussian distribution for health donations, linear link with gaussian distribution for religious and non-health donations) which had a minimal impact on the results. The marginal effects of these alternative models are provided in Supplement A (Table A5).

All models include as covariates: age of head and partner, family unit size, death of child, new birth in household, other unrelated health condition (asthma, arthritis), time (year) dummies, whether they were reporting on pre-shock donations after their health shock (interaction between whether had health shock condition and $\mathrm{t}=-1$ ).

Sample: couples households present in sample from 2001 onwards who experience no changes in couple household composition following a first health shock. 


\section{Discussion}

We find no significant effect of an adverse health shock on the overall probability of donating or on total donations. Instead we find that an adverse health shock causes existing donors to change the charities that they support and to add health charities to their giving portfolio. We find both an increase in the probability of giving to health charities and the amount of money given to health charities. There is no evidence of substitution away from religious giving - if anything, religious giving increases after a health shock. Instead, the substitution is away from other, non-health, non-religious charities. Although there is no decline in the probability of giving to these other charities, there is a decrease in amounts donated. Overall, income and health changes associated with a health shock had a limited effect on charitable giving, indicating that the main effect is likely to be driven by the health shock itself.

Our paper focuses on the direct responses of household members following a health shock of the household head or partner. We have not considered what might happen in the event of mortality, nor have we considered any response from family members living outside of the household. Both of these may be interesting avenues for further research.

Further work might also be done with richer religiosity data - which may have revealed ways in which a health shock affected religiosity. This is important given the important role that religiosity plays in religious giving (and the robustness of religious giving through a health shock). It would also be interesting to extend the analysis to other countries, such as the UK or Canada, which have a smaller share of religious giving and also a different mix of private and public provision in healthcare services.

A lack of data also limited our ability to further examine additional factors that may have provided an understanding on why a stronger response was elicited following cancer compared 
to the other health shock conditions (e.g. prognosis, existing knowledge and resources, degree of social presence and affect towards each health shock condition).

Another avenue for further research would be to investigate other forms of pro-social behaviour such as volunteering and the effect of a health shock on the trade-off between charitable giving and volunteering following a health shock, including whether they are mediated differently.

Nevertheless, our results shed light on the nature of altruism born of suffering. We find no evidence of a general increase in pro-social behaviour (there is no increase in the number of people giving to charity, nor in total donations). Instead, altruism born of suffering appears to manifest as an increase in the desire to support health charities at the expense of other, nonhealth, non-religious charities. The religious sector has consistently received the greatest donations in the US (Giving USA, 2018), and our results indicate that donations to the religious sector remain an important component of a household's charitable giving budget after a health shock. As a result, while households may view the religious sector as core, the health sector and other sectors may be viewed as substitutes.

We interpret altruism born of suffering as an increase in salience of donating to health similar to the impact of a fundraising campaign. The social psychology literature suggests multiple reasons why this might occur, including an increase in the degree of sympathy for healthcare recipients, the formation of ingroups and feelings of reciprocity. There is also likely to be increased awareness and increased opportunity for donating to health charities. Our findings differ to the earlier study by Scharf et al (2017) of the effects of major disaster fundraising appeals in that we find no evidence of an overall lift in donations, only a shift in giving.

One explanation for the different findings in our case could be that a health shock, as a very personal event, causes an increase in giving that is limited to ingroups or those suffering from the event type (Vollhardt, 2009). In comparison, suffering that is non-intentional and collective 
(e.g. natural disasters) or intentional (e.g. violence) is more likely to result in pro-social behaviour towards outgroups and other disadvantaged groups, thereby falling on the higher end of the spectrum (Vollhardt, 2009). Following a disaster appeal, donations increased to both appeal (ingroup) and non-appeal (outgroup) charities.

The main policy implication is for non-profit organisations concerned with attracting and retaining donors. Efforts by non-profit organisations that support individuals in the immediate aftermath of a health shock may facilitate the foundations for reciprocity. In the shorter term, directed efforts could focus on attracting donors following their recovery period. Further work could be undertaken to better leverage the increase in new donors and translate it into donation dollars that are less token. In the longer term, a diversified strategy could focus on retaining donors when responses are expected to decline. 


\section{REFERENCES}

Adena, M. \& Huck, S. (2019), Giving once, giving twice: A two-period field experiment on intertemporal crowding in charitable giving. Journal of Public Economics, 172, pp. 127-134.

Andreoni, J. (1990), Impure altruism and donations to public goods: a theory of warm-glow giving. The Economic Journal, 100, pp. 464-477.

Andreoni, J., Brown, E. \& Rischall, I. (2003), Charitable Giving by Married Couples: Who Decides and Why Does it Matter? The Journal of Human Resources, 38, 1, pp. 111133.

Andreoni, J. \& Serra-Garcia, M. (2018), Time-Inconsistent Charitable Giving. NBER Working Paper No. 22824.

Atkinson, A. (2009), Giving overseas and public policy. Journal of Public Economics, 93, pp. 647-653.

Baetschmann, G. \& Staub, K. (2015), Consistent estimation of the fixed effects ordered logit model. Journal of the Royal Statistical Society Series A, 178, 3, pp. 685-703.

Bekkers, R. \& Wiepking, P. (2011), Who Gives? A Literature Review of Predictors of Charitable Giving Part One: Religion, Education, Age and Socialisation. Voluntary Sector Review, 2, 3, pp. 337-365.

Charities Aid Foundation. (2017) Charitable giving in the USA 2017: An overview of individual giving in the USA. (Charities Aid Foundation).

Dawes, R. \& Thaler, R. (1988), Anomalies: Cooperation. Journal of Economic Perspectives, 2, 3, pp. 187-197.

Filiz-Ozbay, E. \& Uler, N. (2018), Demand for giving to multiple charities: An experimental study. Journal of the European Economic Association, 17, 3, pp. 725-753.

Fong, C. (2007), Evidence from an experiment on charity to welfare recipients: reciprocity, altruism and the empathic responsiveness hypothesis. The Economic Journal, 117, pp. $1008-1024$.

Garcia-Gomez, P. (2011), Institutions, health shocks and labour market outcomes across Europe. Journal of Health Economics, 30, pp. 200-213.

Gillen, G. (2005), Positive Consequences of Surviving a Stroke. American Journal of Occupational Therapy, 59, pp. 346-350.

Giving USA (2018), Annual Report on Philanthropy. Available from https://www.charitynavigator.org/index.cfm?bay=content.view\&cpid=42 (accessed 8 April 2019).

Gneezy, U., Meier, S. \& Rey-Biel, P. (2011), When and Why Incentives (Don't) Work to Modify Behavior. Journal of Economic Perspectives, 25, 4, pp. 191-210.

Goyal, M., Demchuk, A. M., Menon, B. K., Eesa, M., Rempel, J. L., Thornton, J., Roy, D., Jovin, T. G., Willinsky, R. A., Sapkota, B. L., Dowlatshahi, D., Frei, D. F., Kamal, N. R., Montanera, W. J., Poppe, A. Y., Ryckborst, K. J., Silver, F. L., Shuaib, A., Tampieri, D., Williams, D., Bang, O. Y., Baxter, B. W., Burns, P. A., Choe, H., Heo, J.-H., Holmstedt, C. A., Jankowitz, B., Kelly, M., Linares, G., Mandzia, J. L., Shankar, J., Sohn, S.-I., Swartz, R. H., Barber, P. A., Coutts, S. B., Smith, E. E., Morrish, W. F., Weill, A., Subramaniam, S., Mitha, A. P., Wong, J. H., Lowerison, M. W., Sajobi, T. T., Hill, M. D. \& Investigators, E. T. (2015), Randomized assessment of rapid endovascular treatment of ischemic stroke. The New England journal of medicine, 372, 11, pp. 1019-1030.

Halkitis, P. \& Parsons, J. (2003), Intentional unsafe sex (barebacking) among HIV-positive gay men who seek sexual partners on the Internet. AIDS Care, 15, 3, pp. 367-378. 
Harwell, H., Meneses, D., Moceri, C., Rauckhorst, M., Zindler, A. \& Eckel, C. (2015), Did the Ice Bucket Challenge Drain the Philanthropic Reservoir? Working Paper, Economic Research Laboratory, Texas A\&M University.

Jansen, L., Koch, L., Brenner, H. \& Arndt, V. (2010), Quality of life among long-term (>= 5 years) colorectal cancer survivors - systematic review. European Journal of Cancer, 46, 16, pp. 2879-88.

Jones, A. (2011) Models for Health Care. In Clements, M. \& Hendry, D. (Eds.) The Oxford Handbook of Economic Forecasting. (OUP, US).

Jones, A., Rice, N. \& Zantomio, F. (2016), Acute health shocks and labour market outcomes. Available from https://ssrn.com/abstract=2752356 (accessed 30 November 2018).

Konow, J. (2010), Mixed feelings: Theories of and evidence on giving. Journal of Public Economics, 94, pp. 279-297.

Lim, D. \& DeSteno, D. (2016), Suffering and Compassion: The Links Among Adverse Life Experiences, Empathy, Compassion, and Prosocial Behavior. Emotion, 16, 2, pp. 175182.

Lindeboom, M., Llena-Nozal, A. \& Klaauw, v. d. (2016), Health shocks, disability and work. Labour Economics, 43, pp. 186-200.

Liu, K. (2016), Insuring against health shocks: Health insurance and household choices. Journal of Health Economics, 46, pp. 16-32.

Meier, S. (2006), A Survey of Economic Theories and Field Evidence on Pro-Social Behavior. Available from https://ssrn.com/abstract=917187 or http://dx.doi.org/10.2139/ssrn.917187 (accessed 20 June 2018).

Narang, A. \& Nicholas, L. (2017), Out-of-Pocket Spending and Financial Burden Among Medicare Beneficiaries With Cancer. JAMA Oncology, 3, 6, pp. 757-765.

Paez, K., Zhao, L. \& Hwang, W. (2009), Rising Out-Of-Pocket Spending For Chronic Conditions: A Ten-Year Trend. Health Affairs, 28, 1.

Pargament, K. \& Hahn, J. (1986), God and the Just World: Causal and Coping Attributions to God in Health Situations. Journal for the Scientific Study of Religion, 25, 2, pp. 193207.

Reeves, P., Merriam, S. \& Courtnenay, B. (1999), Adaptation to HIV infection: The development of coping strategies over time. Qualitative Health Research, 9, pp. 324331.

Reinstein, D. (2011), Does One Charitable Contribution Come at the Expense of Another? The BE Journal of Economic Analysis and Policy, 11, 1, pp. Article 40.

Rooney, P., Ottoni-Wilhelm, M., Wang, X. \& Han, X. (2019), Dynamics of American Giving: Descriptive Evidence. Available from https://cppp.usc.edu/wpcontent/uploads/2019/03/Rooney-Patrick-dag-01-DynamicsAmericanGiving-v03g.pdf (accessed 2 November 3030).

Scharf, K., Smith, S. \& Ottoni-Wilhelm, M. (2017), Lift and Shift: The Effect of Fundraising Interventions in Charity Space and Time. CESifo Working Paper No. 6694.

Siegel, K., Anderman, S. \& Schrimshaw, E. (2001), Religion and coping with health-related stress. Psychology and Health, 16, 6, pp. 631-653.

Smith, V., Taylor, D., Sloan, F., Johnson, F. \& Desvousges, W. (2001), Do smokers respond to health shocks? Review of Economics and Statistics, 83, 4, pp. 675-687.

Staub, E. (2003), The psychology of good and evil: Why children, adults, and groups help and harm others, (Cambridge University Press, Cambridge).

Staub, E. (2005) The Roots of Goodness: The Fulfillment of Basic Human Needs and the Development of Caring, Helping and Nonaggression, Inclusive Caring, Moral Courage, Active Bystandership, and Altruism Born of Suffering. Moral motivation through the life span. (University of Nebraska Press, Lincoln, NE, US). 
Staub, E. \& Vollhardt, J. (2008), Altruism Born of Suffering: The Roots of Caring and Helping After Victimization and Other Trauma. American Journal of Orthopsychiatry, 78, 3, pp. 267-280.

Tix, A. \& Frazier, P. (1998), The use of religious coping during stressful life events: Main effects, moderation, and mediation. Journal of Consulting and Clinical Psychology, 66, 2, pp. 411-422.

Vollhardt, J. (2009), Altruism Born of Suffering and Prosocial Behavior Following Adverse Life Events: A Review and Conceptualization. Social Justice Research, 22, pp. 53-97.

Vollhardt, J. \& Staub, E. (2011), Inclusive Altruism Born of Suffering: The Relationship Between Adversity and Prosocial Attitudes and Behavior Toward Disadvantaged Outgroups. American Journal of Orthopsychiatry, 81, 3, pp. 307-315.

Wiepking, P. \& Bekkers, R. (2012), Who gives? A literature review of predictors of charitable giving. Part Two: Gender, family composition and income. Voluntary Sector Review, 3, 2, pp. 217-245.

World Bank (2019) Indicators - World Bank Data. (World Bank). 


\section{SUPPLEMENT A: MAIN RESULTS}

Table A1: Impact of a health shock on health, income, healthcare expenditure and religiosity (potential mediators)

\begin{tabular}{lcccc}
\hline & & & Potential mediators & \\
\hline VARIABLES & $(1)$ & $(2)$ & $(3)$ & $(4)$ \\
Health status & Income $(\$)$ & Health expenditure & $\begin{array}{c}\text { Religiosity: } \\
\text { frequency of } \\
\text { religious } \\
\text { attendance (no. of } \\
\text { times per year) }\end{array}$ \\
\hline
\end{tabular}

Time relative to health shock

Reference category: $\mathrm{t}<-2$

(more than 2 years prior)
4,479

Unique households

R-squared
(0.272)

$\begin{array}{ccc}-0.492 * * * & -2,002 & -309 \\ (0.170) & (3,796) & (558) \\ -0.520 * * & -3,876 & 366 \\ (0.229) & (3,932) & (404) \\ -1.130 * * * & -2,123 & 717 \\ (0.275) & (4,054) & (581) \\ -1.589 * * * & -10,177 * * & 1,324 * * \\ (0.262) & (3,970) & (593) \\ -1.745 * * * & -2,736 & 1,127 * * \\ (0.272) & (6,097) & (513)\end{array}$

$(558)$

366

717

(581)

(593)

(513)
$-15.319$

(41.018)

$-15.874$

(44.455)

$-16.378$

(51.704)

11.569

(39.110)

49.046

(61.639)

Cluster-robust standard errors in parentheses

$* * * \mathrm{p}<0.01, * * \mathrm{p}<0.05, * \mathrm{p}<0.1$

Reference category is more than two years prior to the health shock $(\mathrm{t}<-2)$.

(1) Fixed effects ordered logit Blow-Up and Cluster Estimator for self-assessed health status. 1,194 individuals (8,057 observations) with a health shock dropped because of all the same outcomes. Self-reported health status measured on a scale of 1 to 5 where a lower value corresponds to poorer health: (1) poor; (2) fair; (3) good; (4) very good; (5) excellent.

(2) Fixed effects estimates of time relative to health shock and household equivalised income (\$).

(3) Fixed effects estimates of time relative to health shock and health expenditure (\$).

(4) Fixed effects estimates of time relative to health shock and household frequency of attendance at religious services (number of times of attendance per year). Data is only available for the years 2003, 2005 and 2011.

There are no changes in religious preference in the sample, so this is not shown.

Model (1) includes as covariates: age of head and partner, family unit size, death of child, new birth in household, other unrelated health condition (asthma, arthritis) and time (year) dummies.

Models (2) to (4) include as covariates: age of head and partner, family unit size, death of child, new birth in household, other unrelated health condition (asthma, arthritis), time (year) dummies, whether they were reporting on pre-shock donations after their health shock (interaction between whether had health shock condition and $\mathrm{t}=-1$ ).

Sample: couples households present in sample from 2001 onwards who experience no changes in couple household composition following a first health shock. 
Table A2: Dynamics of donating relative to a health shock - probability of donating

\begin{tabular}{|c|c|c|c|c|}
\hline & \multicolumn{4}{|c|}{ Probability of household donating } \\
\hline & (1) & $(2)$ & $(3)$ & $(4)$ \\
\hline VARIABLES & Total & Health & Religious & Other \\
\hline \multicolumn{5}{|l|}{ Time relative to health shock } \\
\hline $\begin{array}{l}\text { Reference category: } \mathrm{t}<-2 \\
\text { (more than } 2 \text { years prior) }\end{array}$ & - & - & - & - \\
\hline \multirow[t]{2}{*}{$\mathrm{t}=-2$ ( 1 to 2 years prior) } & 0.017 & -0.013 & 0.026 & 0.045 \\
\hline & $(0.023)$ & $(0.034)$ & $(0.026)$ & $(0.030)$ \\
\hline \multirow{2}{*}{$\mathrm{t}=-1$ (up to 1 year prior) } & 0.007 & 0.035 & -0.002 & 0.019 \\
\hline & $(0.025)$ & $(0.036)$ & $(0.027)$ & $(0.034)$ \\
\hline \multirow[t]{2}{*}{$\mathrm{t}=0$ (year of health shock) } & -0.016 & 0.007 & 0.013 & 0.029 \\
\hline & $(0.025)$ & $(0.033)$ & $(0.028)$ & $(0.030)$ \\
\hline \multirow[t]{2}{*}{$\mathrm{t}=1$ (up to 1 year after) } & -0.020 & $0.111 * * *$ & 0.002 & -0.031 \\
\hline & $(0.024)$ & $(0.038)$ & $(0.027)$ & $(0.033)$ \\
\hline \multirow[t]{2}{*}{$\mathrm{t}>1$ (more than 1 year after) } & -0.018 & 0.059 & 0.001 & 0.013 \\
\hline & $(0.026)$ & $(0.037)$ & $(0.031)$ & $(0.032)$ \\
\hline Interaction between & -0.062 & 0.018 & -0.050 & -0.043 \\
\hline $\begin{array}{l}\text { whether reported health } \\
\text { shock condition and } t=-1\end{array}$ & $(0.050)$ & $(0.061)$ & $(0.049)$ & $(0.057)$ \\
\hline Observations & 3,133 & 3,126 & 3,132 & 3,132 \\
\hline Unique households & 452 & 452 & 452 & 452 \\
\hline R-squared & 0.011 & 0.016 & 0.020 & 0.010 \\
\hline
\end{tabular}

Cluster-robust standard errors in parentheses

$* * * \mathrm{p}<0.01, * * \mathrm{p}<0.05, * \mathrm{p}<0.1$

Fixed effects estimates of time relative to health shock and probability of donating by charity sector.

Reference category is more than two years prior to the health shock $(\mathrm{t}<-2)$.

All models include as covariates: age of head and partner, family unit size, death of child, new birth in household, other unrelated health condition (asthma, arthritis), time (year) dummies, whether they were reporting on pre-shock donations after their health shock (interaction between whether had health shock condition and $\mathrm{t}=-1)$.

Sample: couples households present in sample from 2001 onwards who experience no changes in couple household composition following a first health shock. 
Table A3: Dynamics of donating relative to a health shock - probability of donating to 'other' sectors

\begin{tabular}{|c|c|c|c|c|c|c|c|c|}
\hline & \multicolumn{8}{|c|}{ Probability of donating by each 'other' charity sector } \\
\hline VARIABLES & $\begin{array}{c}\text { (1) } \\
\text { Combination }\end{array}$ & $\begin{array}{l}(2) \\
\text { Needy }\end{array}$ & $\begin{array}{c}\text { (3) } \\
\text { Education }\end{array}$ & $\begin{array}{c}(4) \\
\text { Youth }\end{array}$ & $\begin{array}{c}(5) \\
\text { Community }\end{array}$ & $\begin{array}{c}\text { (6) } \\
\text { Environment }\end{array}$ & $\begin{array}{c}(7) \\
\text { International } \\
\text { peace }\end{array}$ & $\begin{array}{l}(8) \\
\text { Other }\end{array}$ \\
\hline $\begin{array}{l}\text { Reference category: } t<-2 \\
\text { (more than } 2 \text { years prior) }\end{array}$ & - & - & - & - & - & - & - & - \\
\hline $\mathrm{t}=-2(1$ to 2 years prior $)$ & $\begin{array}{c}0.083 * * \\
(0.037)\end{array}$ & $\begin{array}{l}-0.003 \\
(0.036)\end{array}$ & $\begin{array}{c}-0.066 * * \\
(0.029)\end{array}$ & $\begin{array}{c}0.032 \\
(0.027)\end{array}$ & $\begin{array}{l}-0.009 \\
(0.020)\end{array}$ & $\begin{array}{l}-0.019 \\
(0.022)\end{array}$ & $\begin{array}{l}0.033^{*} \\
(0.020)\end{array}$ & $\begin{array}{l}-0.006 \\
(0.024)\end{array}$ \\
\hline $\mathrm{t}=-1$ (up to 1 year prior) & $\begin{array}{c}0.026 \\
(0.041)\end{array}$ & $\begin{array}{c}0.018 \\
(0.042)\end{array}$ & $\begin{array}{l}-0.012 \\
(0.032)\end{array}$ & $\begin{array}{c}0.012 \\
(0.032)\end{array}$ & $\begin{array}{l}-0.010 \\
(0.023)\end{array}$ & $\begin{array}{c}0.005 \\
(0.026)\end{array}$ & $\begin{array}{c}0.023 \\
(0.020)\end{array}$ & $\begin{array}{l}-0.024 \\
(0.026)\end{array}$ \\
\hline $\mathrm{t}=0$ (year of health shock) & $\begin{array}{c}0.052 \\
(0.036)\end{array}$ & $\begin{array}{l}-0.008 \\
(0.037)\end{array}$ & $\begin{array}{l}-0.055^{*} \\
(0.030)\end{array}$ & $\begin{array}{c}0.016 \\
(0.027)\end{array}$ & $\begin{array}{l}-0.006 \\
(0.021)\end{array}$ & $\begin{array}{l}-0.025 \\
(0.019)\end{array}$ & $\begin{array}{c}0.011 \\
(0.021)\end{array}$ & $\begin{array}{c}0.002 \\
(0.022)\end{array}$ \\
\hline $\mathrm{t}=1$ (up to 1 year after) & $\begin{array}{c}0.054 \\
(0.037)\end{array}$ & $\begin{array}{l}-0.018 \\
(0.039)\end{array}$ & $\begin{array}{l}-0.051^{*} \\
(0.027)\end{array}$ & $\begin{array}{c}0.012 \\
(0.029)\end{array}$ & $\begin{array}{l}-0.011 \\
(0.022)\end{array}$ & $\begin{array}{l}-0.005 \\
(0.024)\end{array}$ & $\begin{array}{l}0.044^{*} \\
(0.023)\end{array}$ & $\begin{array}{l}-0.003 \\
(0.023)\end{array}$ \\
\hline $\mathrm{t}>1$ (more than 1 year after) & $\begin{array}{l}0.071 * \\
(0.041)\end{array}$ & $\begin{array}{l}-0.048 \\
(0.042)\end{array}$ & $\begin{array}{c}-0.064 * * \\
(0.031)\end{array}$ & $\begin{array}{c}0.019 \\
(0.031)\end{array}$ & $\begin{array}{c}0.015 \\
(0.026)\end{array}$ & $\begin{array}{l}-0.000 \\
(0.025)\end{array}$ & $\begin{array}{c}0.013 \\
(0.022)\end{array}$ & $\begin{array}{c}0.005 \\
(0.026)\end{array}$ \\
\hline $\begin{array}{l}\text { Interaction between } \\
\text { whether reported health } \\
\text { shock condition and } t=-1\end{array}$ & $\begin{array}{l}-0.002 \\
(0.061)\end{array}$ & $\begin{array}{l}-0.047 \\
(0.067)\end{array}$ & $\begin{array}{c}0.039 \\
(0.048)\end{array}$ & $\begin{array}{c}0.005 \\
(0.046)\end{array}$ & $\begin{array}{c}0.073 \\
(0.052)\end{array}$ & $\begin{array}{l}-0.035 \\
(0.041)\end{array}$ & $\begin{array}{c}0.063 \\
(0.046)\end{array}$ & $\begin{array}{c}0.014 \\
(0.050)\end{array}$ \\
\hline $\begin{array}{l}\text { Observations } \\
\text { Unique households } \\
\text { R-squared }\end{array}$ & $\begin{array}{c}3,131 \\
452 \\
0.008\end{array}$ & $\begin{array}{c}3,126 \\
452 \\
0.009\end{array}$ & $\begin{array}{c}3,129 \\
452 \\
0.008\end{array}$ & $\begin{array}{c}3,125 \\
452 \\
0.004\end{array}$ & $\begin{array}{c}3,129 \\
452 \\
0.003\end{array}$ & $\begin{array}{c}3,130 \\
452 \\
0.005\end{array}$ & $\begin{array}{c}3,130 \\
452 \\
0.021\end{array}$ & $\begin{array}{c}3,129 \\
452 \\
0.001\end{array}$ \\
\hline
\end{tabular}

Cluster-robust standard errors in parentheses

$* * * \mathrm{p}<0.01, * * \mathrm{p}<0.05, * \mathrm{p}<0.1$

'Other' sectors in Table A2 comprises combination, needy, education, youth, community, environment, international peace and other. Table A3 presents fixed effects

estimates of time relative to health shock and probability of donating by each 'other' charity sector.

All models include as covariates: age of head and partner, family unit size, death of child, new birth in household, other unrelated health condition (asthma, arthritis), time

(year) dummies, whether they were reporting on pre-shock donations after their health shock (interaction between whether had health shock condition and $\mathrm{t}=-1$ ).

Sample: couples households present in sample from 2001 onwards who experience no changes in couple household composition following a first health shock. 
Table A4: Dynamics of donating relative to a health shock - number of charity sectors donated to

\begin{tabular}{lcc}
\hline & Number of charity sectors donated to \\
\hline VARIABLES & OLS & (2) \\
\hline & & \\
Time relative to health shock & & - \\
Reference category: $\mathrm{t}<-2$ & & \\
(more than 2 years prior) & & \\
& & \\
$\mathrm{t}=-2$ (1 to 2 years prior) & 0.056 & 1.034 \\
& $(0.057)$ & $(0.037)$ \\
$\mathrm{t}=-1$ (up to 1 year prior) & 0.052 & 1.037 \\
& $(0.062)$ & $(0.040)$ \\
$\mathrm{t}=0$ (year of health shock) & 0.048 & $(0.035$ \\
& $(0.059)$ & 1.058 \\
$\mathrm{t}=1$ (up to 1 year after) & 0.083 & $(0.042)$ \\
& $(0.064)$ & 1.050 \\
$\mathrm{t}>1$ (more than 1 year after) & 0.068 & $(0.045)$ \\
& $(0.067)$ & 2,983 \\
& & \\
Observations & 3,133 & 417 \\
Unique households & 0.011 & \\
$\mathrm{R}$-squared & 452 &
\end{tabular}

Cluster-robust standard errors in parentheses $* * * \mathrm{p}<0.01, * * \mathrm{p}<0.05, * \mathrm{p}<0.1$

(1) Fixed effects OLS estimates of time relative to health shock and number of charity sectors donated to.

(2) Fixed effects Poisson estimates of time relative to health shock and number of charity sectors donated to. IRR indicates incidence rate ratio.

Reference category is more than two years prior to the health shock $(t<-2)$.

All models include as covariates: age of head and partner, family unit size, death of child, new birth in household, other unrelated health condition (asthma, arthritis), time (year) dummies, whether they were reporting on pre-shock donations after their health shock (interaction between whether had health shock condition and $\mathrm{t}=-1$ ).

Sample: couples households present in sample from 2001 onwards who experience no changes in couple household composition following a first health shock. 
Table A5: Dynamics of donating relative to a health shock - value of donations (alternative models)

\begin{tabular}{|c|c|c|c|c|}
\hline & \multicolumn{4}{|c|}{ Donations (alternative models) - marginal effects } \\
\hline VARIABLES & $\begin{array}{c}\text { (1) } \\
\text { Health: (\$) }\end{array}$ & $\begin{array}{c}(2) \\
\text { Religious }(\$) \\
\end{array}$ & $\begin{array}{c}(3) \\
\text { Other }(\$)\end{array}$ & $\begin{array}{c}4) \\
\text { Total }(\$) \\
\end{array}$ \\
\hline $\begin{array}{l}\text { Time relative to health sho } \\
\text { Reference category: } t<-2 \\
\text { (more than } 2 \text { years prior) }\end{array}$ & - & - & - & - \\
\hline $\mathrm{t}=-2$ ( 1 to 2 years prior $)$ & $\begin{array}{c}0.36 \\
(3.47)\end{array}$ & $\begin{array}{c}15.49 \\
(126.76)\end{array}$ & $\begin{array}{c}10.32 \\
(214.78)\end{array}$ & $\begin{array}{c}-14.41 \\
(235.58)\end{array}$ \\
\hline $\mathrm{t}=-1$ (up to 1 year prior) & $\begin{array}{c}2.52 \\
(4.30)\end{array}$ & $\begin{array}{c}339.95 * * \\
(172.45)\end{array}$ & $\begin{array}{c}173.27 \\
(316.72)\end{array}$ & $\begin{array}{l}621.96 * \\
(337.41)\end{array}$ \\
\hline $\mathrm{t}=0$ (year of health shock $)$ & $\begin{array}{c}0.56 \\
(4.09)\end{array}$ & $\begin{array}{l}411.35^{* *} \\
(204.34)\end{array}$ & $\begin{array}{c}10.82 \\
(219.37)\end{array}$ & $\begin{array}{c}262.53 \\
(269.73)\end{array}$ \\
\hline $\mathrm{t}=1$ (up to 1 year after) & $\begin{array}{l}13.82 \\
(7.57)\end{array}$ & $\begin{array}{l}450.88 * * \\
(222.80)\end{array}$ & $\begin{array}{c}-12.32 \\
(242.13)\end{array}$ & $\begin{array}{c}453.46 \\
(291.98)\end{array}$ \\
\hline $\mathrm{t}>1$ (more than 1 year after) & $\begin{array}{c}5.86 \\
(5.20)\end{array}$ & $\begin{array}{c}160.36 \\
(172.99)\end{array}$ & $\begin{array}{c}-26.73 \\
(276.23)\end{array}$ & $\begin{array}{c}26.64 \\
(290.36)\end{array}$ \\
\hline $\begin{array}{l}\text { Observations } \\
\text { Unique households }\end{array}$ & $\begin{array}{c}3,098 \\
452\end{array}$ & $\begin{array}{c}3,096 \\
452\end{array}$ & $\begin{array}{c}3,130 \\
452\end{array}$ & $\begin{array}{c}3,130 \\
452\end{array}$ \\
\hline
\end{tabular}

Cluster-robust standard errors in parentheses

$* * * \mathrm{p}<0.01, * * \mathrm{p}<0.05, * \mathrm{p}<0.1$

Marginal effects and within-households fixed effects estimates of time relative to health shock and donations by charity sector.

Reference category is more than two years prior to the health shock $(\mathrm{t}<-2)$.

This table outlines results for the next best alternative model:

(1) Health donations are estimated using GLM log link and inverse gaussian.

(2) Religious donations are estimated using GLM linear link and gaussian distribution.

(3) Other donations are estimated using GLM linear link and gaussian distribution.

(4) Total donations are estimated using GLM linear link and gaussian distribution.

Marginal effects are shown in (1)-(4). Zero donations are recoded to $\$ 1$ which is robust to changes in recoding of zero donations to $\$ 0.10$ and $\$ 0.01$.

All models include as covariates: age of head and partner, family unit size, death of child, new birth in household, other unrelated health condition (asthma, arthritis), time (year) dummies, whether they were reporting on pre-shock donations after their health shock (interaction between whether had health shock condition and $\mathrm{t}=-1$ ).

Sample: couples households present in sample from 2001 onwards who experience no changes in couple household composition following a first health shock. 
Table A6: Dynamics of donating relative to a health shock (including income, healthcare expenditure and health status as additional control variables) - value of donations (marginal effects), winsorised at the 5 th and 95 th percentile

\begin{tabular}{|c|c|c|c|c|}
\hline & \multicolumn{4}{|c|}{ Donations - marginal effects } \\
\hline VARIABLES & $\begin{array}{c}(1) \\
\text { Health }(\$) \\
\end{array}$ & $\begin{array}{c}(2) \\
\text { Religious (\$) }\end{array}$ & $\begin{array}{c}(3) \\
\text { Other }(\$) \\
\end{array}$ & $\begin{array}{c}(4) \\
\text { Total }(\$)\end{array}$ \\
\hline $\begin{array}{l}\text { Time relative to health sho } \\
\text { Reference category: } \mathrm{t}<-2 \\
\text { (more than } 2 \text { years prior) }\end{array}$ & - & - & - & - \\
\hline $\mathrm{t}=-2$ ( 1 to 2 years prior) & $\begin{array}{c}4.13 \\
(5.65)\end{array}$ & $\begin{array}{c}118.14 \\
(145.30)\end{array}$ & $\begin{array}{l}119.02 * \\
(66.31)\end{array}$ & $\begin{array}{c}167.13 \\
(198.60)\end{array}$ \\
\hline $\mathrm{t}=-1$ (up to 1 year prior) & $\begin{array}{c}9.91 \\
(6.99)\end{array}$ & $\begin{array}{c}46.36 \\
(149.62)\end{array}$ & $\begin{array}{c}47.07 \\
(65.97)\end{array}$ & $\begin{array}{c}428.52 \\
(226.36)\end{array}$ \\
\hline $\mathrm{t}=0$ (year of health shock) & $\begin{array}{c}3.95 \\
(5.61)\end{array}$ & $\begin{array}{l}267.90 * \\
(151.17)\end{array}$ & $\begin{array}{l}-16.60 \\
(60.79)\end{array}$ & $\begin{array}{c}46.90 \\
(196.22)\end{array}$ \\
\hline $\mathrm{t}=1$ (up to 1 year after) & $\begin{array}{c}25.56 * * * \\
(6.16)\end{array}$ & $\begin{array}{c}150.70 \\
(146.36)\end{array}$ & $\begin{array}{c}-141.60 * * \\
(61.57)\end{array}$ & $\begin{array}{c}-58.75 \\
(203.78)\end{array}$ \\
\hline $\mathrm{t}>1$ (more than 1 year after) & $\begin{array}{c}12.24 * * \\
(5.98)\end{array}$ & $\begin{array}{c}164.38 \\
(161.93)\end{array}$ & $\begin{array}{l}-75.33 \\
(64.85)\end{array}$ & $\begin{array}{l}-169.01 \\
(213.79)\end{array}$ \\
\hline $\begin{array}{l}\text { Observations } \\
\text { Unique households }\end{array}$ & $\begin{array}{c}3,098 \\
452\end{array}$ & $\begin{array}{c}3,096 \\
452\end{array}$ & $\begin{array}{c}3,130 \\
452\end{array}$ & $\begin{array}{c}3,130 \\
452\end{array}$ \\
\hline
\end{tabular}

Cluster-robust standard errors in parentheses

$* * * \mathrm{p}<0.01, * * \mathrm{p}<0.05, * \mathrm{p}<0.1$

Marginal effects and within-households fixed effects estimates of time relative to health shock and donations by charity sector. Values winsorised at the $5^{\text {th }}$ and $95^{\text {th }}$ percentile to reduce the impact of outliers.

Reference category is more than two years prior to the health shock $(\mathrm{t}<-2)$.

(1) Health donations are estimated using GLM linear link and gaussian distribution.

(2) Religious donations are estimated using GLM log link and gamma distribution.

(3) Non-health donations are estimated using GLM log link and gamma distribution.

(4) Total donations are estimated using GLM log link and gamma distribution.

Marginal effects are shown in (1)-(4). Zero donations are recoded to $\$ 1$ which is robust to changes in recoding of zero donations to $\$ 0.10$ and $\$ 0.01$. Donations are winsorised (bottom and top 5\%).

All models include as covariates: age of head and partner, family unit size, death of child, new birth in household, other unrelated health condition (asthma, arthritis), time (year) dummies, whether they were reporting on pre-shock donations after their health shock (interaction between whether had health shock condition and $\mathrm{t}=-1$ ), as well as income, healthcare expenditure and health status.

Sample: couples households present in sample from 2001 onwards who experience no changes in couple household composition following a first health shock. 


\section{SUPPLEMENT B: CONSTRUCTION OF TIMING FLAGS}

Supplement B details the construction of timing flags in terms of:

1. When a health shock occurred in relation to the donation period; and

2. When a health shock occurred in relation to health variables.

\section{When a health shock occurred in relation to the donation period}

\section{Health shock}

Household heads are asked: "has a doctor ever told you that you have had a stroke [heart attack, cancer]?". In terms of the time since health shock, from 1999- 2003, household heads are asked: "how long have you had this condition?". This differed from 2005-2015, and household heads are instead asked: "how old were you the first time you had a stroke [heart attack, cancer]?" and "have you had another stroke [heart attack] at any time in the past 12 months/a second or subsequent stroke [heart attack] since that first one?" All questions were also asked for spouses.

From these questions, we construct two variables: (1) whether a household head/spouse had a health shock, and (2) the time since health shock. For 2001-2003, time since health shock is taken as how long they reported they have had the condition. For 2005-2015, time since health shock is calculated as the difference between the household head/spouse's age at the interview date and the age they reported they first had the condition. We then use the time since health shock to calculate the key variable: (3) the date of the health shock.

\section{Donation period}

Household heads are asked the same questions about whether they donated to an organisation of a particular sector and the dollar amount of donations by sector from 2001-2015. These questions are asked in relation to the calendar year prior the survey wave ${ }^{11}$. For example, in the 2001 wave, household heads are asked: "altogether, what was the total dollar value of all donations you and your family made in 2000 towards [sector] purposes?"

\section{Construction of timing variable - when pro-social behaviour is the outcome variable}

We construct the timing variable as the time of the donations relative to the health shock:

(1) $t<-2$ : more than two calendar years prior to the health shock;

(2) $\mathrm{t}=-2$ : two calendar years prior to the health shock;

(3) $\mathrm{t}=-1$ : in the calendar year prior to the health shock;

(4) $t=0$ : in the calendar year of the health shock;

(5) $t=1$ : in the calendar year following the health shock; and,

(6) $t>1$ : more than one calendar year following the health shock.

\footnotetext{
${ }^{11}$ Also applies to variables such as income, frequency of religious attendance, healthcare expenditure.
} 


\section{Extension of $t=-1$}

At $\mathrm{t}=-1$ there may be two potential scenarios:

- Reporting on donations in the year prior to the health shock period (donations for $t=-1$ ) BEFORE the health shock in the current survey year; or

- Reporting on donations in the year prior to the health shock period (donations for $t=-1$ ) AFTER the health shock in the current survey year.

For example, a health shock in the 2005 wave aligns with the 2004 calendar year for donations, so an individual reporting a health shock in 2005 would be categorised as $t=-1$. However, depending on the date of the interview relative to the health shock, the individual may be reporting on donations prior to their health shock either before or after the health shock. This may result in reporting bias where those who had their survey after the health shock may inflate their reported donations - they may donate more following their health shock, which they combine with their 2004 donations. We account for this by exploring the impact at $\mathrm{t}=-1$ when the interaction term is included in the main model.

\section{When a health shock occurred in relation to health variables}

\section{Construction of timing variable - when health status is the outcome variable}

In the survey, many variables such as general health status ${ }^{12}$ do not stipulate a time period, but the question implies the current period. For example, for general health status household heads are asked: "would you say your health in general is excellent, very good, good, fair, or poor?" We therefore construct the timing variable around the date of the interview at the survey wave:

(1) $t<-2$ : health shock occurred more than two years prior to the survey wave;

(2) $t=-2$ : health shock occurred one to two years prior to the survey wave;

(3) $t=-1$ : health shock occurred up to one year prior to the survey wave;

(4) $t=0$ : health shock occurred in the year of the survey wave;

(5) $t=1$ : health shock occurred up to one year following the survey wave; and

(6) $t>1$ : health shock occurred more than one year following the survey wave.

\footnotetext{
${ }^{12}$ Also includes religious preference.
} 


\section{SUPPLEMENT C: ADDITIONAL RESULTS}

\section{Contents}

C1. Multiple health shocks - primary vs secondary health shocks

C2. By health shock condition

C3. By health condition status prior to health shock

C4. By age

C5. By who had the health shock in the household

C6. Religiosity

C7. State of residence 


\section{C1. MULTIPLE HEALTH SHOCKS - PRIMARY VS SECONDARY HEALTH SHOCKS}

Our base sample focuses on charitable giving following a first health shock, so B1 compares primary versus secondary health shocks. Charitable giving may diminish with recurrences as there may be some adaptation in response and the health shock becomes less of a 'shock'. In addition, income and health status could be further impacted with a secondary health shock.

The results show that there is still a greater and significant probability of donating to health at $\mathrm{t}=1$ for a primary health shock $(7.8 \%, \mathrm{p}<0.05)$. For a secondary health shock at $\mathrm{t}=1$ and $\mathrm{t}>1$, the coefficient estimates increase although it is insignificant with greater variability. While donations to health are token and insignificant for both primary and secondary health shocks, coefficient estimates are slightly lower for secondary health shocks at $t=0$ and $t=1$.

Table C1: Dynamics of donating relative to a health shock - multiple health shocks

\begin{tabular}{lc}
\hline VARIABLES & Probability of donating to health \\
\hline Time relative to health shock & - \\
Reference category: $\mathrm{t}<-2$ & \\
(more than 2 years prior) & \\
& \\
Primary health shock & -0.008 \\
$\mathrm{t}=-2$ (1 to 2 years prior) & $(0.030)$ \\
& 0.019 \\
$\mathrm{t}=-1$ (up to 1 year prior) & $(0.030)$ \\
& -0.013 \\
$\mathrm{t}=0$ (year of health shock) & $(0.027)$ \\
& $0.078^{* *}$ \\
$\mathrm{t}=1$ (up to 1 year after) & $(0.032)$ \\
& 0.030 \\
$\mathrm{t}>1$ (more than 1 year after) & $(0.030)$ \\
& \\
Secondary health shock & -0.007 \\
$\mathrm{t}=0$ (year of health shock) & $(0.044)$ \\
$\mathrm{t}=1$ (up to 1 year after) & 0.084 \\
$\mathrm{t}>1$ (more than 1 year after) & $(0.064)$ \\
& 0.050 \\
Observations & $(0.042)$ \\
Unique households & \\
Clusquared & 4,584 \\
& 596 \\
& 0.011 \\
\hline
\end{tabular}

Cluster-robust standard errors in parentheses

$* * * \mathrm{p}<0.01, * * \mathrm{p}<0.05, * \mathrm{p}<0.1$

Fixed effects estimates of time relative to health shock and probability of donating by charity sector.

All models include as covariates: age of head and partner, family unit size, death of child, new birth in household, other unrelated health condition (asthma, arthritis), time (year) dummies, whether they were reporting on pre-shock donations after their health shock (interaction between whether had health shock condition and $\mathrm{t}=-1$ ).

Sample: couples households present in sample from 2001 onwards who experience no changes in couple household composition following a first health shock. 


\section{C2. BY HEALTH SHOCK CONDITION}

Different health shock conditions could elicit different responses given the differences in population affected, prognosis, treatment, knowledge and resources. Stroke and heart attack typically affect older people and have a fairly standard diagnosis, treatment and management. There have also been recent developments in treatment, for example, endovascular clot retrieval is a relatively new and highly effective treatment for stroke which has helped to reduce mortality and improve outcomes (Goyal et al., 2015). In contrast, cancer can affect a greater proportion of younger people and can often be associated with poorer prognosis than stroke and heart attack. For some cancers (e.g. mesothelioma, pancreatic cancer), there is no cure and a high mortality rate, with limited research, knowledge and resources. High profile cases like Olivia Newton-John may also influence affect and social presence of the condition in society. Cancer may therefore elicit a different response compared to individuals with a stroke or heart attack. Error! Reference source not found. shows the dynamics of the probability of donating to each charity sector relative to the health shock by each health shock condition. Our results indicate that there is a significant increase in the probability of a household donating to health for those with cancer or heart attack at $t=1$ by $13 \%(p<0.01)$ and $16 \%(\mathrm{p}<0.1)$ respectively, but no significant change for those who had a stroke. The significant increase for cancer remained at $\mathrm{t}>1(11 \%, \mathrm{p}<0.05)$. The limited changes for stroke in comparison to heart attack and cancer may be explained by poorer health status during the year of the health shock and beyond, although income and healthcare expenditure do not appear to be as impacted (Table C3-Table C5). 
Table C2: Dynamics of donating relative to a health shock - probability of donating to health, by health shock condition

\begin{tabular}{lccc}
\hline & \multicolumn{3}{c}{ Probability of donating to health } \\
\hline VARIABLES & $(1)$ & $(2)$ & $(4)$ \\
& Stroke & Heart attack & Cancer \\
Reference category: $\mathrm{t}<-2$ & & & - \\
(more than 2 years prior) & - & - & \\
& & & \\
Time relative to health shock & & & -0.011 \\
$\mathrm{t}=-2$ (1 to 2 years prior) & -0.010 & -0.023 & $(0.045)$ \\
& $(0.111)$ & $(0.058)$ & 0.058 \\
$\mathrm{t}=-1$ (up to 1 year prior) & -0.108 & -0.010 & $(0.042)$ \\
& $(0.116)$ & $(0.081)$ & 0.030 \\
$\mathrm{t}=0$ (year of health shock) & $-0.170 *$ & 0.024 & $(0.043)$ \\
& $(0.095)$ & $(0.053)$ & $0.130^{* * *}$ \\
$\mathrm{t}=1$ (up to 1 year after) & -0.084 & $0.161 *$ & $(0.045)$ \\
& $(0.093)$ & $(0.096)$ & $0.105 * *$ \\
$\mathrm{t}>1$ (more than 1 year after) & -0.103 & -0.005 & $(0.046)$ \\
& $(0.122)$ & $(0.079)$ & \\
& & & 2,081 \\
Observations & 372 & 612 & 282 \\
Unique households & 60 & 94 & 0.029 \\
$\mathrm{R}$-squared & 0.033 & 0.031 & \\
\hline
\end{tabular}

Cluster-robust standard errors in parentheses

$* * * \mathrm{p}<0.01, * * \mathrm{p}<0.05, * \mathrm{p}<0.1$

Fixed effects estimates of time relative to health shock and probability of donating to health by health shock condition.

All models include as covariates: age of head and partner, family unit size, death of child, new birth in household, other unrelated health condition (asthma, arthritis), time (year) dummies, whether they were reporting on pre-shock donations after their health shock (interaction between whether had health shock condition and $\mathrm{t}=-1$ ).

Sample: couples households present in sample from 2001 onwards who experience no changes in couple household composition following a first health shock.

Note that there is a difference in the total number of households for stroke, heart attack and cancer in this table $(n=436)$ compared to the main model $(n=452)$. This is due to 16 households experiencing multiple health shocks at similar dates, so we have not attributed these households to one health shock condition. As the sample focuses on first health shocks, these 16 household's observations are censored from $\mathrm{t}=0$ onwards. So the main model captures their pre-shock donations $(\mathrm{t}<0)$ in terms of a general health shock condition, but this table does not (because we do not attribute their pre-shock donations to a particular health shock condition). 
From Error! Reference source not found., stroke was the condition that was associated with an insignificant reduction in the probability of donating to health at $t=1$, compared to heart attack and cancer. The following tables investigate the effect of each health shock condition on health status, income and healthcare expenditure to understand why this may occur.

The limited changes for stroke in comparison to heart attack and cancer may be explained by poorer health status during the year of the health shock and beyond, although income and healthcare expenditure do not appear to be as impacted.

Table C3: Impact of different health shock conditions on health

\begin{tabular}{lccc}
\hline & $(1)$ & $(2)$ & $(3)$ \\
VARIABLES & Stroke & Heart attack & Cancer \\
\hline & & & - \\
Reference category: $\mathrm{t}<-2$ & - & - & \\
(more than 2 years prior) & & & \\
& & & 0.031 \\
Time relative to health shock & & -0.494 & $(0.237)$ \\
$\mathrm{t}=-2$ (1 to 2 years prior) & -0.406 & $(0.412)$ & $-1.142 * * *$ \\
& $(0.672)$ & $-1.658 * * *$ & $(0.280)$ \\
$\mathrm{t}=-1$ (up to 1 year prior) & $-1.774 * * *$ & $-1.925 * * *$ & $-0.789 * * *$ \\
& $(0.686)$ & $(0.524)$ & $(0.277)$ \\
$\mathrm{t}=0$ (year of health shock) & $-2.222^{* * *}$ & $-2.170 * * *$ & $-1.334 * * *$ \\
& $(0.710)$ & $(0.599)$ & $(0.300)$ \\
$\mathrm{t}=1$ (up to 1 year after) & $-2.336 * * *$ & $-1.292 * *$ & $-0.820 * * *$ \\
& $(0.700)$ & $(0.542)$ & $(0.287)$ \\
$\mathrm{t}>1$ (more than 1 year after) & $-2.697 * * *$ & & 3,000 \\
& $(0.756)$ & 942 & \\
\end{tabular}

Cluster-robust standard errors in parentheses

$* * * \mathrm{p}<0.01, * * \mathrm{p}<0.05, * \mathrm{p}<0.1$

Reference category is more than two years prior to the health shock $(\mathrm{t}<-2)$.

Fixed effects ordered logit Blow-Up and Cluster Estimator for self-assessed health status.

(1) 149 individuals (901 observations) with stroke dropped because of all the same outcomes.

(2) 242 individuals (1,506 observations) with heart attack dropped because of all the same outcomes.

(3) 731 individuals (5,348 observations) with cancer dropped because of all the same outcomes.

Self-reported health status measured on a scale of 1 to 5 where a lower value corresponds to poorer health: (1) poor; (2) fair; (3) good; (4) very good; (5) excellent.

Sample: couples households present in sample from 2001 onwards who experience no changes in couple household composition following a first health shock.

All models include as covariates: age of head and partner, family unit size, death of child, new birth in household, other unrelated health condition (asthma, arthritis), time (year) dummies, whether they were reporting on pre-shock donations after their health shock (interaction between whether had health shock condition and $\mathrm{t}=-1)$. 
Table C4: Impact of different health shock conditions on income

\begin{tabular}{lccc}
\hline & $(1)$ & $(2)$ & $(3)$ \\
VARIABLES & Stroke & Heart attack & Cancer \\
\hline Reference category: $\mathrm{t}<-2$ & & & - \\
(more than 2 years prior) & - & - & \\
& & & \\
Time relative to health shock & & & $-6,560$ \\
$\mathrm{t}=-2$ (1 to 2 years prior) & 859 & 13,463 & $(4,250)$ \\
& $(4,329)$ & $(13,456)$ & $-9,901^{* *}$ \\
$\mathrm{t}=-1$ (up to 1 year prior) & $-3,011$ & 14,376 & $-8,368^{* *}$ \\
& $(6,124)$ & $(12,191)$ & $(3,399)$ \\
$\mathrm{t}=0$ (year of health shock) & $-2,445$ & 21,320 & $-11,081^{* *}$ \\
& $(5,401)$ & $(17,409)$ & $(4,790)$ \\
$\mathrm{t}=1$ (up to 1 year after) & $-3,771$ & $-16,581$ & $-10,125^{* *}$ \\
& $(6,760)$ & $(15,907)$ & $(4,811)$ \\
$\mathrm{t}>1$ (more than 1 year after) & $-11,867 *$ & 30,972 & 2,087 \\
& $(6,868)$ & $(27,354)$ & 282 \\
& & & 0.033 \\
\hline Observations & 374 & 612 & 94 \\
Unique households & 60 & 0.037 & \\
R-squared & 0.107 & & \\
\hline
\end{tabular}

Cluster-robust standard errors in parentheses

$* * * \mathrm{p}<0.01, * * \mathrm{p}<0.05, * \mathrm{p}<0.1$

Reference category is more than two years prior to the health shock $(\mathrm{t}<-2)$.

Fixed effects estimates of time relative to health shock and household equivalised income (\$).

All models include as covariates: age of head and partner, family unit size, death of child, new birth in household, other unrelated health condition (asthma, arthritis), time (year) dummies, whether they were reporting on pre-shock donations after their health shock (interaction between whether had health shock condition and $\mathrm{t}=-1$ ).

Sample: couples households present in sample from 2001 onwards who experience no changes in couple. household composition following a first health shock. 
Table C5: Impact of different health shock conditions on healthcare expenditure

\begin{tabular}{lccc}
\hline VARIABLES & $\begin{array}{c}(1) \\
\text { Stroke }\end{array}$ & $\begin{array}{c}(2) \\
\text { Heart attack }\end{array}$ & $\begin{array}{c}(3) \\
\text { Cancer }\end{array}$ \\
\hline $\begin{array}{l}\text { Reference category: } \mathrm{t}<-2 \\
\text { (more than 2 years prior) }\end{array}$ & - & - \\
& & & \\
Time relative to health shock & & & \\
$\mathrm{t}=-2$ (1 to 2 years prior) & 8 & -284 & -653 \\
$\mathrm{t}=-1$ (up to 1 year prior) & $(843)$ & $(660)$ & $(760)$ \\
& 556 & $1,615^{*}$ & 660 \\
$\mathrm{t}=0$ (year of health shock) & $(901)$ & $(906)$ & $(600)$ \\
& -100 & $2,380^{*}$ & 185 \\
$\mathrm{t}=1$ (up to 1 year after) & $(725)$ & $(1,216)$ & $(732)$ \\
& 622 & 681 & $1,527 * *$ \\
$\mathrm{t}>1$ (more than 1 year after) & $(1,177)$ & $(929)$ & $(766)$ \\
& 569 & $1,962^{*}$ & 895 \\
& $(1,312)$ & $(1,150)$ & $(630)$ \\
Observations & & & \\
Unique households & 374 & 612 & 2,087 \\
$\mathrm{R}$-squared & 60 & 94 & 282 \\
\hline
\end{tabular}

Cluster-robust standard errors in parentheses

$* * * \mathrm{p}<0.01, * * \mathrm{p}<0.05, * \mathrm{p}<0.1$

Reference category is more than two years prior to the health shock $(\mathrm{t}<-2)$.

Fixed effects estimates of time relative to health shock and healthcare expenditure (\$).

All models include as covariates: age of head and partner, family unit size, death of child, new birth in household, other unrelated health condition (asthma, arthritis), time (year) dummies, whether they were reporting on pre-shock donations after their health shock (interaction between whether had health shock condition and $\mathrm{t}=-1$ ).

Sample: couples households present in sample from 2001 onwards who experience no changes in couple household composition following a first health shock. 


\section{C3. BY HEALTH CONDITION STATUS PRIOR TO HEALTH SHOCK}

Prior to a health shock, an individual may have an already diagnosed health condition such as diabetes, hypertension, lung disease, cardiac condition, asthma or arthritis. As a result, these individuals may already be engaging with the health system in some capacity, which may influence salience of need towards the health sector.

The results show that those with a health condition prior to the health shock had a significant increase in the probability of donating to health at $t=1$ and $t>1$ (C3.2), although these donations are token.

Table C6: Dynamics of donating relative to a health shock - by health condition status prior to health shock

\begin{tabular}{|c|c|c|c|c|}
\hline & \multicolumn{2}{|c|}{$\begin{array}{l}\text { No health condition prior to health } \\
\text { shock }\end{array}$} & \multicolumn{2}{|c|}{$\begin{array}{l}\text { Diagnosed health condition prior to } \\
\text { health shock }\end{array}$} \\
\hline VARIABLES & $\begin{array}{c}\text { (1) } \\
\text { Probability of } \\
\text { donating to health }\end{array}$ & $\begin{array}{c}\text { (2) } \\
\text { Health donations }\end{array}$ & $\begin{array}{c}\text { (3) } \\
\text { Probability of } \\
\text { donating to health }\end{array}$ & $\begin{array}{c}\text { (4) } \\
\text { Health donations }\end{array}$ \\
\hline $\begin{array}{l}\text { Reference category: } t<-2 \\
\text { (more than } 2 \text { years prior) }\end{array}$ & - & - & - & - \\
\hline \multicolumn{5}{|c|}{ Time relative to health shock } \\
\hline $\mathrm{t}=-2$ ( 1 to 2 years prior $)$ & $\begin{array}{l}-0.064 \\
(0.077)\end{array}$ & $\begin{array}{c}27.17 \\
(48.09)\end{array}$ & $\begin{array}{l}-0.001 \\
(0.037)\end{array}$ & $\begin{array}{l}-10.66 \\
(45.04)\end{array}$ \\
\hline $\mathrm{t}=-1$ (up to 1 year prior) & $\begin{array}{c}0.027 \\
(0.064)\end{array}$ & $\begin{array}{c}70.89 \\
(59.34)\end{array}$ & $\begin{array}{c}0.041 \\
(0.044)\end{array}$ & $\begin{array}{c}77.83 \\
(107.04)\end{array}$ \\
\hline $\mathrm{t}=0$ (year of health shock) & $\begin{array}{l}-0.044 \\
(0.069)\end{array}$ & $\begin{array}{c}-2.52 \\
(59.78)\end{array}$ & $\begin{array}{c}0.015 \\
(0.038)\end{array}$ & $\begin{array}{l}-67.86 \\
(53.46)\end{array}$ \\
\hline $\mathrm{t}=1$ (up to 1 year after) & $\begin{array}{c}0.068 \\
(0.066)\end{array}$ & $\begin{array}{c}-5.96 \\
(30.34)\end{array}$ & $\begin{array}{c}0.134 * * * \\
(0.041)\end{array}$ & $\begin{array}{c}29.29 \\
(91.78)\end{array}$ \\
\hline$t>1$ (more than 1 year & -0.031 & 54.20 & $0.087 * *$ & -103.10 \\
\hline & $(0.070)$ & $(79.67)$ & $(0.041)$ & (106.08) \\
\hline Observations & 818 & 812 & 2,235 & 2,214 \\
\hline Unique households & 115 & 115 & 320 & 320 \\
\hline R-squared & 0.026 & - & 0.023 & - \\
\hline
\end{tabular}

Cluster-robust standard errors in parentheses

$* * * \mathrm{p}<0.01, * * \mathrm{p}<0.05, * \mathrm{p}<0.1$

Reference category is more than two years prior to the health shock $(\mathrm{t}<-2)$

No health condition is defined as no diagnosis of diabetes, hypertension, lung disease, cardiac condition, asthma and arthritis. These conditions were selected based on data availability.

(1) and (3): Fixed effects estimates of time relative to health shock and probability of donating to health.

(2) and (4): Marginal effects and within-households fixed effects estimates of time relative to health shock and health donations. Health donations are estimated using GLM linear link and Gaussian distribution.

All models include as covariates: age of head and partner, family unit size, death of child, new birth in household, other unrelated health condition (asthma, arthritis), time (year) dummies, whether they were reporting on pre-shock donations after their health shock (interaction between whether had health shock condition and $\mathrm{t}=-1$ ).

Sample: couples households present in sample from 2001 onwards who experience no changes in couple household composition following a first health shock. 


\section{C4. BY AGE}

\section{C4.1 Age}

Age has been found to be positively associated with charitable giving, with older people more likely to donate (Charities Aid Foundation., 2017). Those over 65 who donate, on average, make the largest donations (Giving USA, 2018).

The results indicate that the increase in probability of donating to health at $t=1$ is largely driven by those that are under 65 years. Donations are insignificant and variable for both age groups. While there is a significant increase in religious donations in those under 65 years, there some larger but insignificant coefficient estimates for health donations at $t=1$ for those over 65 years.

The base sample consists of couples who experience no changes in household composition following a health shock. This therefore excludes households with a death of the head or partner, which was done to minimise issues such as philanthropic bequests and legacies that may have confounded our findings. As a result, the mean age of heads and partners in our sample is 56 and 54 respectively. This may explain why the sample of those over 65 years is small ( $\mathrm{n}=84$ households), limiting statistical power and not providing results as expected for this age group. 
Table C7: Dynamics of donating relative to a health shock - by age group

\begin{tabular}{|c|c|c|c|c|}
\hline & \multicolumn{2}{|c|}{$>=65$ years } & \multicolumn{2}{|c|}{$<65$ years } \\
\hline VARIABLES & $\begin{array}{c}\text { (1) } \\
\text { Probability of } \\
\text { donating to health }\end{array}$ & $\begin{array}{c}(2) \\
\text { Health donations }\end{array}$ & $\begin{array}{c}(3) \\
\text { Probability of } \\
\text { donating to health }\end{array}$ & $\begin{array}{l}\text { (4) } \\
\text { Health donations }\end{array}$ \\
\hline $\begin{array}{l}\text { Reference category: } \mathrm{t}<-2 \\
\text { (more than } 2 \text { years prior) }\end{array}$ & - & - & - & - \\
\hline $\begin{array}{l}\text { Time relative to health } \\
\text { shock }\end{array}$ & & & & \\
\hline $\mathrm{t}=-2$ ( 1 to 2 years prior $)$ & $\begin{array}{c}0.048 \\
(0.066)\end{array}$ & $\begin{array}{l}-63.08 \\
(40.86)\end{array}$ & $\begin{array}{l}-0.030 \\
(0.041)\end{array}$ & $\begin{array}{c}17.59 \\
(44.04)\end{array}$ \\
\hline $\mathrm{t}=-1$ (up to 1 year prior) & $\begin{array}{c}0.077 \\
(0.088)\end{array}$ & $\begin{array}{l}49.65 \\
(64.74)\end{array}$ & $\begin{array}{c}0.029 \\
(0.040)\end{array}$ & $\begin{array}{c}81.17 \\
(97.44)\end{array}$ \\
\hline $\mathrm{t}=0$ (year of health shock) & $\begin{array}{c}0.037 \\
(0.063)\end{array}$ & $\begin{array}{l}-106.51 \\
(70.02)\end{array}$ & $\begin{array}{l}-0.005 \\
(0.039)\end{array}$ & $\begin{array}{l}-38.07 \\
(41.09)\end{array}$ \\
\hline $\mathrm{t}=1$ (up to 1 year after) & $\begin{array}{c}0.028 \\
(0.077)\end{array}$ & $\begin{array}{c}146.86 \\
(131.49)\end{array}$ & $\begin{array}{c}0.131 * * * \\
(0.043)\end{array}$ & $\begin{array}{l}-17.84 \\
(60.49)\end{array}$ \\
\hline $\begin{array}{l}t>1 \text { (more than } 1 \text { year } \\
\text { after) }\end{array}$ & $\begin{array}{l}0.124 \\
(0.090)\end{array}$ & $\begin{array}{c}-33.46 \\
(126.17)\end{array}$ & $\begin{array}{c}0.043 \\
(0.043)\end{array}$ & $\begin{array}{l}-56.77 \\
(79.61)\end{array}$ \\
\hline $\begin{array}{l}\text { Observations } \\
\text { Unique households } \\
\text { R-squared }\end{array}$ & $\begin{array}{c}593 \\
84 \\
0.046\end{array}$ & $\begin{array}{c}578 \\
84 \\
- \\
-\end{array}$ & $\begin{array}{c}2,441 \\
348 \\
0.017\end{array}$ & $\begin{array}{c}2,428 \\
348 \\
-\end{array}$ \\
\hline
\end{tabular}

Cluster-robust standard errors in parentheses

$* * * \mathrm{p}<0.01, * * \mathrm{p}<0.05, * \mathrm{p}<0.1$

Reference category is more than two years prior to the health shock $(\mathrm{t}<-2)$.

(1) and (3): Fixed effects estimates of time relative to health shock and probability of donating to health.

(2) and (4): Marginal effects and within-households fixed effects estimates of time relative to health shock and health donations. Health donations are estimated using GLM linear link and Gaussian distribution.

All models include as covariates: age of head and partner, family unit size, death of child, new birth in household, other unrelated health condition (asthma, arthritis), time (year) dummies, whether they were reporting on pre-shock donations after their health shock (interaction between whether had health shock condition and $\mathrm{t}=-1$ ).

Sample: couples households present in sample from 2001 onwards who experience no changes in couple household composition following a first health shock. 


\section{C4.2 Deaths}

When deaths are included in the sample, the significant increase in the probability of donating to health and the corresponding significant reduction to other sectors at $t=1$ remains similar to the main model.

Table C8: Dynamics of donating relative to a health shock - deaths included in sample

(1)

VARIABLES

Probability of donating to health

Reference category: $\mathrm{t}<-2$

(more than 2 years prior)

Time relative to health shock

$\mathrm{t}=-2$ ( 1 to 2 years prior) $\quad-0.027$

(0.027)

$\mathrm{t}=-1$ (up to 1 year prior) $\quad 0.026$

$\mathrm{t}=0$ (year of health shock) $\quad-0.016$

(0.027)

$\mathrm{t}=1$ (up to 1 year after) $\quad 0.076^{* *}$

$\mathrm{t}>1$ (more than 1 year after) $\quad 0.038$

$(0.032)$

Observations $\quad 4,644$

Unique households $\quad 785$

$\begin{array}{ll}\text { R-squared } & 0.012\end{array}$

Cluster-robust standard errors in parentheses

$* * * \mathrm{p}<0.01, * * \mathrm{p}<0.05, * \mathrm{p}<0.1$

Reference category is more than two years prior to the health shock $(\mathrm{t}<-2)$.

Fixed effects estimates of time relative to health shock and probability of donating to health.

All models include as covariates: age of head and partner, family unit size, death of child, new birth in household, other unrelated health condition (asthma, arthritis), time (year) dummies, whether they were reporting on pre-shock donations after their health shock (interaction between whether had health shock condition and $\mathrm{t}=-1$ ).

Sample: couples households present in sample from 2001 onwards who experience no changes in couple household composition following a first health shock. 


\section{C5. BY WHO HAD THE HEALTH SHOCK IN THE HOUSEHOLD}

There may be heterogeneity in response by whether the household head or partner had the health shock in the household. There may be a greater income shock following the household head's health shock which may impact on charitable giving. There may also be a different set of psychological processes and response mechanisms depending on who experiences the health shock.

In addition, males and females have different tastes for giving and those in couples households bargain over charitable giving, with conflicts largely resolved in favour of the household head's preference (Andreoni et al., 2003). However, bargaining power could shift towards the household member with the health shock.

In our sample, around 55\% of household heads had a health shock compared to $45 \%$ of partners. The results indicate a similar probability of donating to health regardless of whether the head or partner experienced the health shock. 
Table C9: Dynamics of donating relative to a health shock - by whether head or partner head health shock

Probability of donating to health

(1)

Head had health shock
(2)

Partner had health shock

Reference category: $\mathrm{t}<-2$

(more than 2 years prior)

Time relative to health shock

$\mathrm{t}=-2$ ( 1 to 2 years prior)

$-0.008-0.034$

$(0.045) \quad(0.054)$

$\mathrm{t}=-1$ (up to 1 year prior)

0.037

0.021

$(0.051)$

(0.048)

$\mathrm{t}=0$ (year of health shock)

0.008

$-0.014$

(0.046)

$(0.047)$

$\mathrm{t}=1$ (up to 1 year after)

$0.108 * *$

$0.111^{* * *}$

$(0.053)$

$(0.054)$

$\mathrm{t}>1$ (more than 1 year after)

0.032

0.071

$(0.055)$

(0.050)

Observations

1,725

1,389

Unique households

249

201

R-squared

0.022

0.026

Cluster-robust standard errors in parentheses

$* * * \mathrm{p}<0.01, * * \mathrm{p}<0.05, * \mathrm{p}<0.1$

Fixed effects estimates of time relative to health shock and probability of donating to health.

All models include as covariates: age of head and partner, family unit size, death of child, new birth in household, other unrelated health condition (asthma, arthritis), time (year) dummies, whether they were reporting on pre-shock donations after their health shock (interaction between whether had health shock condition and $\mathrm{t}=-1$ ).

Sample: couples households present in sample from 2001 onwards who experience no changes in couple household composition following a first health shock. 


\section{C6. RELIGIOSITY}

\section{C6.1 By religiosity subgroup}

Religiosity may have an impact on charitable giving. Given that religion discusses the suffering of others and emphasises the importance of helping others, those who are religious may be more responsive following a health shock compared to those who are not religious. Those who are religious may also increase charitable giving towards the religious sector, while those who are not religious may increase charitable giving towards the health sector.

We investigate this by examining the degree of religiosity prior to the health shock, using the frequency of household religious attendance before the health shock. We define 'nonreligious' as those not attending religious services before the health shock and 'religious' as those attending religious services at least once a year before the health shock.

The results indicate that in comparison to non-religious households, there is a significant increase in the probability of donating to health by religious households at $t=1$, but the impact on the probability of donating to the religious sector is minimal. Religious households were more likely to increase donations to the health sector at $\mathrm{t}=1$ compared to non-religious households, although the dollar amount is token. Religious households' donations to the religious sector remained large in dollar terms at $t=0$ and $t=1$, although it was not a significant increase in percentage terms.

These results indicate that religious households are more responsive, which may be due to the greater level of baseline behaviour translating into a higher propensity for charitable giving following a health shock. While our definition resulted in around $20 \%$ of the sample classified as 'non-religious' and $80 \%$ classified as 'religious', similar results were found when we investigated alternative definitions such as 'non-religious' and 'religious' classified as religious attendance less than 52 times a year and more than or equal to 52 times a year respectively. 


\section{Probability of donating}

Table C10: Dynamics of donating relative to a health shock - probability of donating, non-religious households

\begin{tabular}{|c|c|c|c|c|}
\hline \multicolumn{5}{|c|}{ Probability of household donating - non-religious households } \\
\hline VARIABLES & $\begin{array}{c}(1) \\
\text { Total }\end{array}$ & $\begin{array}{c}(2) \\
\text { Health } \\
\end{array}$ & $\begin{array}{c}(3) \\
\text { Religious } \\
\end{array}$ & $\begin{array}{c}(4) \\
\text { Other } \\
\end{array}$ \\
\hline $\begin{array}{l}\text { Time relative to health sho } \\
\text { Reference category: } t<-2 \\
\text { (more than } 2 \text { years prior) }\end{array}$ & - & - & - & - \\
\hline $\mathrm{t}=-2$ ( 1 to 2 years prior) & $\begin{array}{l}-0.061 \\
(0.059)\end{array}$ & $\begin{array}{l}-0.060 \\
(0.057)\end{array}$ & $\begin{array}{l}-0.066 \\
(0.052)\end{array}$ & $\begin{array}{l}-0.070 \\
(0.058)\end{array}$ \\
\hline $\mathrm{t}=-1$ (up to 1 year prior) & $\begin{array}{l}-0.037 \\
(0.077)\end{array}$ & $\begin{array}{l}-0.039 \\
(0.091)\end{array}$ & $\begin{array}{c}-0.028 \\
(0.064)\end{array}$ & $\begin{array}{l}-0.100 \\
(0.088)\end{array}$ \\
\hline $\mathrm{t}=0$ (year of health shock) & $\begin{array}{l}-0.086 \\
(0.076)\end{array}$ & $\begin{array}{l}-0.034 \\
(0.076)\end{array}$ & $\begin{array}{c}0.006 \\
(0.061)\end{array}$ & $\begin{array}{c}-0.143^{*} \\
(0.075)\end{array}$ \\
\hline $\mathrm{t}=1$ (up to 1 year after) & $\begin{array}{l}-0.083 \\
(0.065)\end{array}$ & $\begin{array}{c}0.018 \\
(0.094)\end{array}$ & $\begin{array}{c}-0.000 \\
(0.068)\end{array}$ & $\begin{array}{c}-0.230 * * * \\
(0.084)\end{array}$ \\
\hline $\mathrm{t}>1$ (more than 1 year after) & $\begin{array}{l}-0.093 \\
(0.071)\end{array}$ & $\begin{array}{c}0.048 \\
(0.087)\end{array}$ & $\begin{array}{l}-0.023 \\
(0.066)\end{array}$ & $\begin{array}{c}-0.242 * * * \\
(0.073)\end{array}$ \\
\hline $\begin{array}{l}\text { Interaction between } \\
\text { whether reported health } \\
\text { shock condition and } t=-1\end{array}$ & $\begin{array}{c}0.050 \\
(0.112)\end{array}$ & $\begin{array}{c}0.017 \\
(0.129)\end{array}$ & $\begin{array}{c}-0.058 \\
(0.066)\end{array}$ & $\begin{array}{l}-0.029 \\
(0.141)\end{array}$ \\
\hline $\begin{array}{l}\text { Observations } \\
\text { Unique households } \\
\text { R-squared }\end{array}$ & $\begin{array}{c}498 \\
71 \\
0.100 \\
\end{array}$ & $\begin{array}{c}497 \\
71 \\
0.051 \\
\end{array}$ & $\begin{array}{c}498 \\
71 \\
0.071 \\
\end{array}$ & $\begin{array}{c}498 \\
71 \\
0.084 \\
\end{array}$ \\
\hline
\end{tabular}

Cluster-robust standard errors in parentheses

$* * * \mathrm{p}<0.01, * * \mathrm{p}<0.05, * \mathrm{p}<0.1$

Fixed effects estimates of time relative to health shock and probability of donating by charity sector for nonreligious households (households that did not attend any religious services prior to the health shock).

All models include as covariates: age of head and partner, family unit size, death of child, new birth in household, other unrelated health condition (asthma, arthritis), time (year) dummies, whether they were reporting on pre-shock donations after their health shock (interaction between whether had health shock condition and $\mathrm{t}=-1$ ).

Sample: couples households present in sample from 2001 onwards who experience no changes in couple household composition following a first health shock. 
Table C11: Dynamics of donating relative to a health shock - probability of donating, religious households

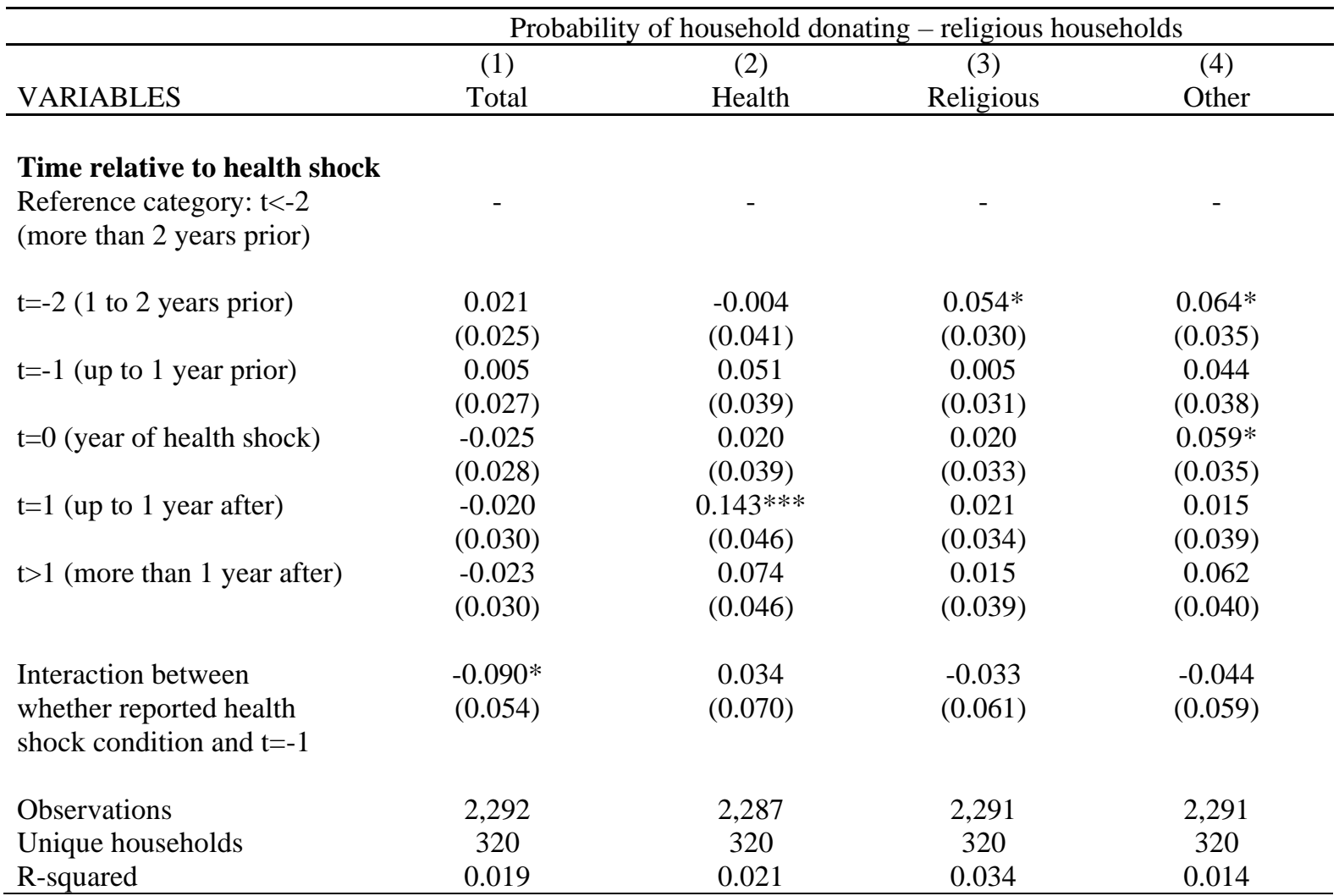

Cluster-robust standard errors in parentheses

$* * * \mathrm{p}<0.01, * * \mathrm{p}<0.05, * \mathrm{p}<0.1$

Fixed effects estimates of time relative to health shock and probability of donating by charity sector for religious households (households that attended at least one religious services prior to the health shock).

All models include as covariates: age of head and partner, family unit size, death of child, new birth in household, other unrelated health condition (asthma, arthritis), time (year) dummies, whether they were reporting on pre-shock donations after their health shock (interaction between whether had health shock condition and $\mathrm{t}=-1$ ).

Sample: couples households present in sample from 2001 onwards who experience no changes in couple household composition following a first health shock. 


\section{Donations}

Table C12: Dynamics of donating relative to a health shock - value of donations, non-religious households

\begin{tabular}{|c|c|c|c|}
\hline & \multicolumn{3}{|c|}{ Donations - marginal effects } \\
\hline VARIABLES & $\begin{array}{c}(1) \\
\text { Health }(\$) \\
\end{array}$ & $\begin{array}{c}(2) \\
\text { Religious (\$) } \\
\end{array}$ & $\begin{array}{c}(3) \\
\text { Other }(\$) \\
\end{array}$ \\
\hline $\begin{array}{l}\text { Time relative to health sho } \\
\text { Reference category: } t<-2 \\
\text { (more than } 2 \text { years prior) }\end{array}$ & - & - & - \\
\hline $\mathrm{t}=-2$ ( 1 to 2 years prior $)$ & $\begin{array}{c}66.76 \\
(124.37)\end{array}$ & $\begin{array}{l}-53.30 \\
(33.16)\end{array}$ & $\begin{array}{c}-463.10^{*} \\
(195.91)\end{array}$ \\
\hline $\mathrm{t}=-1$ (up to 1 year prior) & $\begin{array}{c}409.64 \\
(417.70)\end{array}$ & $\begin{array}{l}-14.13 \\
(33.88)\end{array}$ & $\begin{array}{l}-419.80 \\
(240.02)\end{array}$ \\
\hline $\mathrm{t}=0$ (year of health shock) & $\begin{array}{l}-36.79 \\
(50.13)\end{array}$ & $\begin{array}{l}-11.64 \\
(31.07)\end{array}$ & $\begin{array}{c}-923.91 * * * \\
(269.94)\end{array}$ \\
\hline $\mathrm{t}=1$ (up to 1 year after) & $\begin{array}{c}12.72 \\
(36.69)\end{array}$ & $\begin{array}{c}3.47 \\
(35.68)\end{array}$ & $\begin{array}{c}-703.48 * * \\
(242.81)\end{array}$ \\
\hline $\mathrm{t}>1$ (more than 1 year after) & $\begin{array}{l}-10.25 \\
(53.47)\end{array}$ & $\begin{array}{l}-21.36 \\
(34.94)\end{array}$ & $\begin{array}{c}-1080.71 * * * \\
(288.26)\end{array}$ \\
\hline $\begin{array}{l}\text { Observations } \\
\text { Unique households }\end{array}$ & $\begin{array}{c}491 \\
71 \\
\end{array}$ & $\begin{array}{c}498 \\
71 \\
\end{array}$ & $\begin{array}{c}497 \\
71 \\
\end{array}$ \\
\hline
\end{tabular}

Unique households

$* * * \mathrm{p}<0.01, * * \mathrm{p}<0.05, * \mathrm{p}<0.1$

Marginal effects and within-households fixed effects estimates of time relative to health shock and donations by charity sector.

Reference category is more than two years prior to the health shock $(\mathrm{t}<-2)$.

(1) Health donations are estimated using GLM linear link and Gaussian distribution.

(2) Religious donations are estimated using GLM log link and gamma distribution.

(3) Non-health donations are estimated using GLM log link and gamma distribution.

Marginal effects are shown in (1), (2) and (3). Zero donations are recoded to \$1 which is robust to changes in recoding of zero donations to $\$ 0.10$ and $\$ 0.01$.

All models include as covariates: age of head and partner, family unit size, death of child, new birth in household, other unrelated health condition (asthma, arthritis), time (year) dummies, whether they were reporting on pre-shock donations after their health shock (interaction between whether had health shock condition and $\mathrm{t}=-1$ ).

Sample: couples households present in sample from 2001 onwards who experience no changes in couple household composition following a first health shock. 
Table C13: Dynamics of donating relative to a health shock - value of donations, religious households

\begin{tabular}{|c|c|c|c|}
\hline & \multicolumn{3}{|c|}{ Donations - marginal effects } \\
\hline VARIABLES & $\begin{array}{c}(1) \\
\text { Health (\$) }\end{array}$ & $\begin{array}{c}(2) \\
\text { Religious (\$) }\end{array}$ & $\begin{array}{c}(3) \\
\text { Other }(\$) \\
\end{array}$ \\
\hline Time relative to health shoc & & & \\
\hline $\begin{array}{l}\text { Reference category: } \mathrm{t}<-2 \\
\text { (more than } 2 \text { years prior) }\end{array}$ & - & - & - \\
\hline $\mathrm{t}=-2$ ( 1 to 2 years prior $)$ & $\begin{array}{l}-17.24 \\
(38.54)\end{array}$ & $\begin{array}{c}404.93 \\
(261.79)\end{array}$ & $\begin{array}{l}505.75 * * \\
(155.81)\end{array}$ \\
\hline $\mathrm{t}=-1$ (up to 1 year prior) & $\begin{array}{c}16.91 \\
(57.49)\end{array}$ & $\begin{array}{l}-93.38 \\
(254.76)\end{array}$ & $\begin{array}{l}292.92^{*} \\
(143.45)\end{array}$ \\
\hline $\mathrm{t}=0$ (year of health shock) & $\begin{array}{l}-54.75 \\
(48.70)\end{array}$ & $\begin{array}{c}369.57 \\
(274.44)\end{array}$ & $\begin{array}{c}184.47 \\
(137.09)\end{array}$ \\
\hline $\mathrm{t}=1$ (up to 1 year after) & $\begin{array}{c}30.34 \\
(83.44)\end{array}$ & $\begin{array}{c}109.72 \\
(265.09)\end{array}$ & $\begin{array}{c}-12.73 \\
(144.26)\end{array}$ \\
\hline t>1 (more than 1 year after) & $\begin{array}{c}-66.20 \\
(104.91)\end{array}$ & $\begin{array}{c}39.94 \\
(307.14)\end{array}$ & $\begin{array}{c}248.18 \\
(154.99)\end{array}$ \\
\hline Observations & 2,270 & 2,262 & 2,290 \\
\hline Unique households & 320 & 320 & 320 \\
\hline
\end{tabular}

Cluster-robust standard errors in parentheses

$* * * \mathrm{p}<0.01, * * \mathrm{p}<0.05, * \mathrm{p}<0.1$

Marginal effects and within-households fixed effects estimates of time relative to health shock and donations by charity sector.

Reference category is more than two years prior to the health shock $(t<-2)$.

(1) Health donations are estimated using GLM linear link and Gaussian distribution.

(2) Religious donations are estimated using GLM log link and gamma distribution.

(3) Non-health donations are estimated using GLM log link and gamma distribution.

Marginal effects are shown in (1), (2) and (3). Zero donations are recoded to $\$ 1$ which is robust to changes in recoding of zero donations to $\$ 0.10$ and $\$ 0.01$.

All models include as covariates: age of head and partner, family unit size, death of child, new birth in household, other unrelated health condition (asthma, arthritis), time (year) dummies, whether they were reporting on pre-shock donations after their health shock (interaction between whether had health shock condition and $\mathrm{t}=-1$ ).

Sample: couples households present in sample from 2001 onwards who experience no changes in couple household composition following a first health shock. 


\section{C6.2 Religiosity as a control variable}

Table C23 demonstrates the impact of adding religiosity (household frequency of attendance at religious services per year) as a control variable. Given that data for the frequency of attendance at religious services is only available for 2003, 2005 and 2011, we undertake a comparison for these years only.

The results indicate that adding religiosity as a control variable has limited influence on the effect of a health shock on charitable giving.

Table C14: Dynamics of donating relative to a health shock - probability of donating to health, impact of religiosity $(2003,2005,2011)$

\begin{tabular}{|c|c|c|}
\hline VARIABLES & $\begin{array}{c}(1) \\
\text { Main model }\end{array}$ & $\begin{array}{c}\text { (2) } \\
\text { Main model + } \\
\text { religiosity } \\
\end{array}$ \\
\hline $\begin{array}{l}\text { Time relative to health shock } \\
\text { Reference category: } t<-2 \\
\text { (more than } 2 \text { years prior) }\end{array}$ & - & - \\
\hline $\mathrm{t}=-2$ ( 1 to 2 years prior $)$ & $\begin{array}{c}0.025 \\
(0.050)\end{array}$ & $\begin{array}{c}0.024 \\
(0.050)\end{array}$ \\
\hline $\mathrm{t}=-1$ (up to 1 year prior) & $\begin{array}{c}0.125 * * \\
(0.062)\end{array}$ & $\begin{array}{c}0.122 * * \\
(0.062)\end{array}$ \\
\hline $\mathrm{t}=0$ (year of health shock) & $\begin{array}{c}0.150 * * * \\
(0.056)\end{array}$ & $\begin{array}{c}0.148 * * * \\
(0.057)\end{array}$ \\
\hline $\mathrm{t}=1$ (up to 1 year after) & $\begin{array}{c}0.245 * * * \\
(0.070)\end{array}$ & $\begin{array}{c}0.235 * * * \\
(0.070)\end{array}$ \\
\hline $\mathrm{t}>1$ (more than 1 year after) & $\begin{array}{c}0.169 * * * \\
(0.065)\end{array}$ & $\begin{array}{c}0.161^{* *} \\
(0.065)\end{array}$ \\
\hline $\begin{array}{l}\text { Potential mediator } \\
\text { Religiosity - household frequency of } \\
\text { attendance at religious services (per } \\
\text { annum) }\end{array}$ & - & $\begin{array}{c}0.000 \\
(0.000)\end{array}$ \\
\hline $\begin{array}{l}\text { Observations } \\
\text { Unique households } \\
\text { R-squared }\end{array}$ & $\begin{array}{c}1,227 \\
442 \\
0.047\end{array}$ & $\begin{array}{c}1,220 \\
442 \\
0.047\end{array}$ \\
\hline
\end{tabular}

Cluster-robust standard errors in parentheses

$* * * \mathrm{p}<0.01, * * \mathrm{p}<0.05, * \mathrm{p}<0.1$

Fixed effects estimates of time relative to health shock and probability of donating to health - impact of religiosity on the main model.

Frequency of attendance at religious services data was only available for 2003, 2005, 2011, so models (1) and (2) are based on these years.

All models include as covariates: age of head and partner, family unit size, death of child, new birth in household, other unrelated health condition (asthma, arthritis), time (year) dummies, whether they were reporting on pre-shock donations after their health shock (interaction between whether had health shock condition and $\mathrm{t}=-1$ ).

Sample: couples households present in sample from 2001 onwards who experience no changes in couple household composition following a first health shock. 


\section{C7. STATE OF RESIDENCE}

A household's state of residence could influence charitable giving as states may differ in terms of number and types of non-profit organisations, state and local taxes, and preferences and attitudes.

State of residence is omitted from our vector of control variables on the basis that $91 \%$ of the sample do not change their state of residence from 2001 to 2015 and for those that change states, the state effects are likely to be captured within the individual's fixed effects. Including state of residence as a control variable also causes issues in the fixed effects ordered logit Blow-Up and Cluster Estimator due to the low number of observations for some states when we estimate the impact of a health shock on health status.

The following tables demonstrate that the results are robust when state of residence is included as a control variable.

Table C15: Dynamics of donating relative to a health shock - with state of residence as a control variable

\begin{tabular}{lc}
\hline & \multicolumn{1}{c}{$(1)$} \\
VARIABLES & Probability of donating to health \\
\hline Reference category: $\mathrm{t}<-2$ & - \\
(more than 2 years prior) & \\
& \\
Time relative to health shock & -0.015 \\
$\mathrm{t}=-2$ (1 to 2 years prior) & $(0.035)$ \\
& 0.028 \\
$\mathrm{t}=-1$ (up to 1 year prior) & $(0.036)$ \\
& 0.006 \\
$\mathrm{t}=0$ (year of health shock) & $(0.034)$ \\
& $0.109 * * *$ \\
$\mathrm{t}=1$ (up to 1 year after) & $(0.038)$ \\
& 0.054 \\
$\mathrm{t}>1$ (more than 1 year after) & $(0.038)$ \\
& 3,109 \\
& 450 \\
Observations & 0.035 \\
Unique households & \\
\hline
\end{tabular}

Cluster-robust standard errors in parentheses

$* * * \mathrm{p}<0.01, * * \mathrm{p}<0.05, * \mathrm{p}<0.1$

Reference category is more than two years prior to the health shock $(\mathrm{t}<-2)$.

Fixed effects estimates of time relative to health shock and probability of donating to health.

All models include as covariates: age of head and partner, family unit size, death of child, new birth in household, other unrelated health condition (asthma, arthritis), time (year) dummies, whether they were reporting on pre-shock donations after their health shock (interaction between whether had health shock condition and $\mathrm{t}=-1)$.

Sample: couples households present in sample from 2001 onwards who experience no changes in couple household composition following a first health shock. 